\title{
Cellular Origin of Hepatocellular Carcinoma
}

\author{
Doris Schneller • Peter Angel \\ Division of Signal Transduction and Growth Control, DKFZ-ZMBH Alliance, \\ German Cancer Research Center (DKFZ), Heidelberg, Germany
}

Author for Correspondence: Peter Angel, Division of Signal Transduction and Growth Control, DKFZ-ZMBH Alliance, German Cancer Research Center (DKFZ), Heidelberg, Germany. Email: p.angel@dkfz.de

Doi: http://dx.doi.org/10.15586/hepatocellularcarcinoma.2019.ch1

\begin{abstract}
Molecular features of hepatocellular carcinoma affect patient prognosis and treatment efficiency. This chapter provides an overview of the relevant studies conducted to identify the cell of origin of hepatocellular carcinoma with a special focus on the controversy of hepatocytes versus hepatic progenitors as the main tumor-initiating cell. Furthermore, we introduce the concept of cancer stem cells (CSCs) and highlight recent publications covering this topic in relation to liver cancer. More precisely, we concentrate on the origin of CSCs, discuss accepted markers and the need to define a consistent combination of them that can be utilized to clearly define this heterogeneous cell type, summarize important signaling pathways that govern the stemness, and describe state-of-the-art assays to isolate and evaluate CSCs. We focus on their contributions to oncogenesis and tumor heterogeneity, as well as their feature to resist chemo- and radiotherapy. Finally, the potential of using CSC markers for diagnostic purposes and therapeutic approaches targeting these cells is addressed.
\end{abstract}

Keywords: cancer stem cells; cell of origin; CSC markers; hepatic progenitor cells; tumor-initiating cell

In: Hepatocellular Carcinoma. Janina E.E. Tirnitz-Parker (Editor), Codon Publications, Brisbane, Australia. ISBN: 978-0-9944381-8-8. 2019; Doi: http://dx.doi.org/10.15586/ hepatocellularcarcinoma.2019

Copyright: The Authors.

License: This open access article is licensed under Creative Commons Attribution 4.0 International (CC BY 4.0). https://creativecommons.org/licenses/by-nc/4.0/ 


\section{INTRODUCTION}

Liver cancer, with hepatocellular carcinoma (HCC) representing approximately $90 \%$ of all cases, is the third leading cause of cancer-related deaths worldwide $(1,2)$. The main risk factors for developing HCC are well known and include chronic liver damage caused by inflammation and fibrosis, alcohol abuse, infection by hepatitis $\mathrm{B}$ or hepatitis $\mathrm{C}$ virus, metabolic syndrome, and ingestion of the fungal metabolite aflatoxin $\mathrm{Bl}(1)$. Therapeutic approaches include surgical resection, transarterial chemoembolization (TACE), local radiofrequency ablation (RFA), and organ transplantation (3). However, most cases of HCC are diagnosed at advanced stages for which efficient therapies are limited (4). Unresectable HCC cases are treated with sorafenib, a multikinase inhibitor, with modest survival benefits (5). It is commonly known that molecular features of HCC affect patient prognosis and treatment efficiency. For example, human HCC harboring vascular endothelial growth factor A (VEGFA) gene amplification is more sensitive to sorafenib treatment (6) and in vivo RNAi screening has identified Mapk14 as a target to overcome therapy resistance (7). Therefore, it is essential to comprehensively elucidate the mechanisms underlying hepatocarcinogenesis. Over the past decade, there has been a considerable improvement in the understanding of the molecular pathogenesis of HCC $(8,9)$. The landscape of genetic alterations in HCC has been clearly characterized. High-level DNA amplifications were found in chromosome 6p21 (VEGFA) and 1lq13 (fibroblast growth factor, FGF19; Cyclin D1, CNND1), as well as homozygous deletions in chromosome 9 (cyclindependent kinase inhibitor 2A, CDKN2A). Mutations in the telomerase reverse transcriptase (TERT) promoter are the most frequent, affecting $60 \%$ of HCC patients. The next most prevalent mutations are found in the tumor suppressor gene TP53 and catenin beta 1(CTNNB1) (25-30\%), followed by genes with lowfrequency mutation rates (e.g., AXIN1; AT-rich interactive domain-containing protein, ARID2, ARID1A; tuberous sclerosis protein, TSC1/TSC2; ribosomal protein S6 kinase alpha 3, RPS6KA3; Kelch-like ECH-associated protein, KEAP1; MLL2). TP53-mutated human HCCs revealed increased Aurora A kinase (AURKA) expression, hypersensitivity to treatment with conformation-changing AURKA inhibitors, and a positive correlation between AURKA and the proto-oncogene MYC expression (10). These findings help to define some of the core deregulated pathways in HCC $(8,11)$. The role of chronic tissue damage, inflammation, and metabolism, as well as signaling pathways controlling the immune response during hepatocarcinogenesis, has been extensively studied (12-20).

Yet, there is still a need to gain a much deeper insight into the mechanisms responsible for liver cancer initiation; that is, the cellular origin; and progression; that is, propagation and maintenance; to facilitate the detection of more reliable tumor markers for diagnostic and prognostic applications, and the development of new targeted therapy approaches for liver cancer.

In this chapter, we will review relevant studies conducted to identify the cell of origin of HCC with a special focus on the controversy of hepatocytes versus hepatic progenitors as the main tumor-initiating cell (TIC). Furthermore, we will introduce the concept of cancer stem cells (CSCs) and highlight recent publications covering this topic in relation to liver cancer. More precisely, we will concentrate on the origin of CSCs, discuss accepted markers and the need to define a 
consistent combination of them that can be utilized to clearly define this heterogeneous cell type, summarize important signaling pathways that govern the stemness, and describe state-of-the-art assays to isolate and evaluate CSCs. We will focus on their contributions to oncogenesis and tumor heterogeneity, as well as on their feature to resist chemo- and radiotherapy. Finally, the potential of using CSC markers for diagnostic purposes and therapeutic approaches targeting these cells will be addressed.

\section{CELL OF ORIGIN OF HCC}

HCC is highly heterogeneous in cellular morphology, genetic landscape, and response to therapeutic interventions $(21,22)$. Two major molecular clusters (proliferation and non-proliferation) with distinguishing enrichment in prognostic signatures, pathway activation, and tumor phenotype have been identified (8). Interestingly, one subtype of the more aggressive proliferation class was specifically enriched in markers of progenitor cells $(23,24)$. These observations have led to several hypotheses about the cell(s) of origin of liver cancer with hepatocytes and hepatic progenitor cells (HPCs) as the main cellular elements whose malignant transformation could initiate hepatocarcinogenesis. Many studies carried out in the last years have attempted to shed light on the controversy of the origin of the TIC. In general, mouse primary HPCs, lineage-committed hepatoblasts, and differentiated adult hepatocytes were shown to be targetable by oncogenic transformation and to enable tumorigenesis via activation of diverse cell-specific pathways (25) (Figure1). However, the nature of target cells affected susceptibility to transformation, tumor histopathology, and global gene expression profiles. Tumors of HCC-like pattern predominantly derived from mature adult hepatocytes underlined that tumorigenic cells keep at least part of the differentiation program typically seen in the original cell, while HPC tumors adopt a more primitive mesenchymal-like state (25). Of importance, distinct genetic changes are needed for the oncogenic transformation of different hepatic lineage cells. In addition, the type of genetic alteration predisposing towards carcinogenesis further contributes to the phenotypic and molecular diversity of HCC. In non-transformed HPCs as well as hepatocytes, loss of the tumor suppressor p53 resulted in chromosomal imbalances and increased clonogenic capacity, and formation of tumors with bilinear differentiation after transplantation into immunocompromized mice (26). In the following sections, we will discuss the different evidences supporting HPCs or hepatocytes as the cellular origin of HCC (Table 1).

\section{Hepatic progenitor cells as tumor-initiating cells of HCC}

Over the past years, several genetic and chemically induced HCC preclinical mouse models have been established (27-30). In fact, some of them suggest a progenitor cell origin of liver tumors (Figure 1, Table 1). HPCs isolated from mouse embryos were able to generate liver carcinomas resembling human HCC after isolation and ex vivo genetic manipulation followed by transplantation into the livers of recipient mice (31). Progenitor cells in mouse liver were shown to give rise to cancer due to interleukin-6 (IL-6)-driven transformation accompanied 


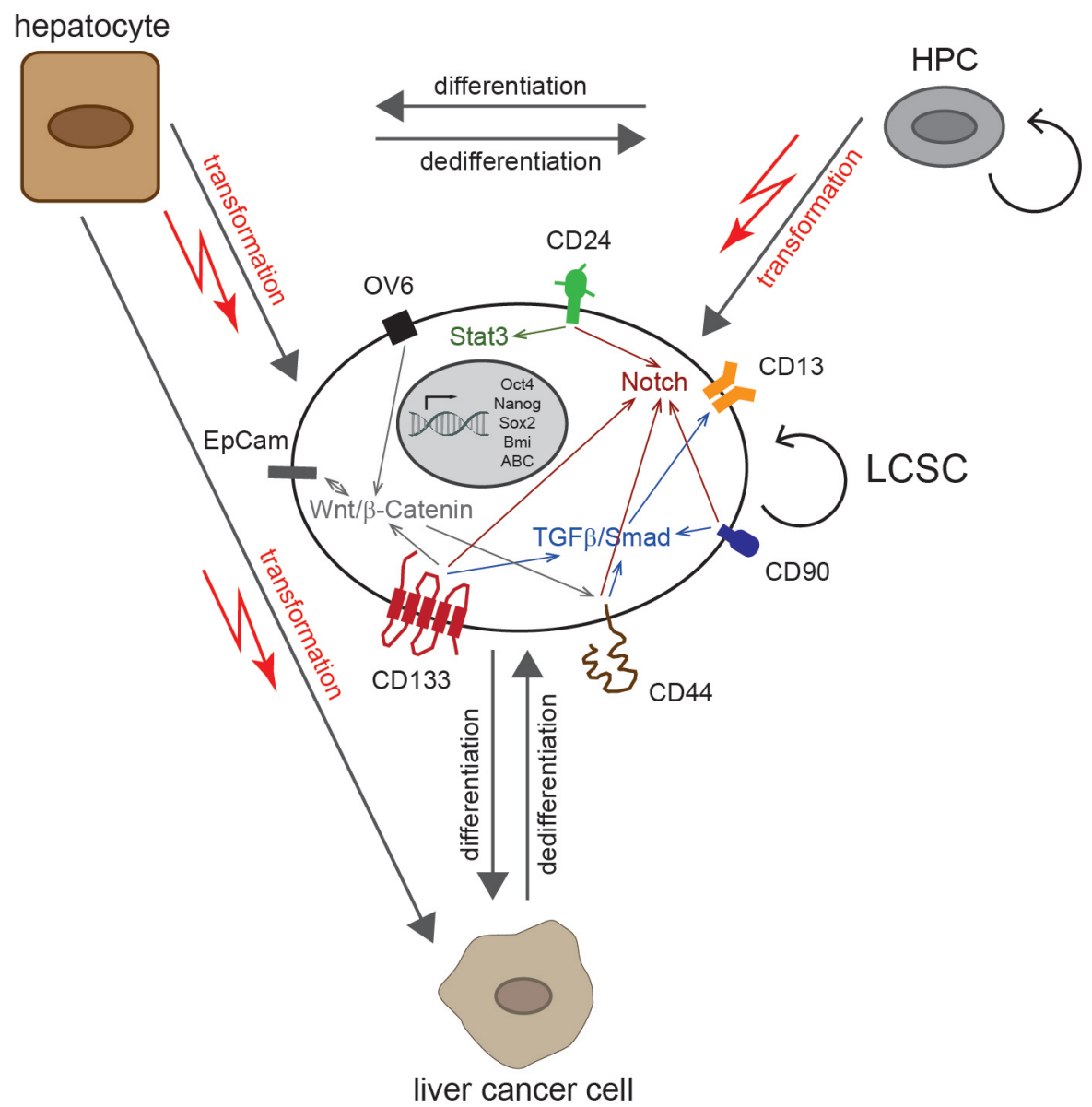

Figure 1 LCSCs_origin and characterization. Hepatocytes, hepatic progenitor cells (HPC) and differentiated liver cancer cells are potential cellular origins of liver cancer stem cells (LCSC) via transformation or dedifferentiation. Different markers were shown to be specific for LCSCs. Signaling pathways associated with these markers are depicted.

by inactivated transforming growth factor beta (TGF $\beta$ ) signaling (32). In contrast, constant TGF $\beta$ stimulation in cirrhotic liver was shown to promote the neoplastic transformation of HPCs to hepatic TICs that facilitate hepatocarcinogenesis through an miR216a/phosphatase and tensin homolog (PTEN)/Akt-dependent pathway (33). Both studies support a role of HPCs as the cell of origin of HCC but point to a contradictory role for TGF $\beta$ during their malignant transformation, potentially due to the interaction with other signaling pathways.

Mice with attenuated Hippo signaling activity within the liver expanded progenitor cells and subsequently showed liver tumor formation (34). These findings are also relevant to human liver cancer, where the majority of human HCCs show elevated levels of nuclear yes-associated protein (YAP), which is indicative of attenuated Hippo signaling in these tumors $(35,36)$. Similarly, deletion of the tumor 


\section{TABLE 1 The different hypotheses about the cell of origin of HCC}

\begin{tabular}{|c|c|c|c|}
\hline $\begin{array}{l}\text { Proposed } \\
\text { cell of origin }\end{array}$ & Model & Pathways & Reference \\
\hline \multirow[t]{11}{*}{ HPCs } & Orthotopic transplantation into C57BL/6 mice & cIAP1, YAP & $(31)$ \\
\hline & $\mathrm{elf}^{+/-}$mice & IL-6, TGF $\beta$ & $(32)$ \\
\hline & Xenotransplantation into NOD-SCID mice & TGF $\beta$, Akt & (33) \\
\hline & mst $1 / 2$ and savl conditional mutant mice & Hippo & (34) \\
\hline & Xenotransplantation into nu/nu mice & Nf2/Merlin & $(37)$ \\
\hline & AFP-NICD mice & Notch & (38) \\
\hline & Ctnnbl conditional mutant mice & Wnt & $(40)$ \\
\hline & P240 PR-SET7 $7^{\triangle \mathrm{HepA}}$ mice & STAT3 & $(43)$ \\
\hline & DEN/2-AAF/PH treatment of F-344 rats & AP-1/JUN & $(44)$ \\
\hline & 2-AAF/PH treatment of F-344/N Slc rats & retinoid receptors & $(45)$ \\
\hline & $\begin{array}{l}\text { Epcam }{ }^{\text {CreERT2 }} \text { transgenic mice } \\
\text { DDC } \\
\text { Xenotransplantation into NOD-SCID mice }\end{array}$ & Wnt & $(46)$ \\
\hline \multirow[t]{7}{*}{ Hepatocytes } & Tsc l/Sqstm $1^{\text {thep }}$ and Sqstml ${ }^{\Delta \text { hep }} /$ MUP mice & $\begin{array}{l}\mathrm{p} 62 / \mathrm{NRF} 2 / \mathrm{mTORCl} / \\
\mathrm{c}-\mathrm{Myc}\end{array}$ & $(48)$ \\
\hline & $\begin{array}{l}\text { Stat } 3^{\mathrm{fff}} \text { mice, } \mathrm{I} 16^{-/-} \\
\text {AAV injection } \\
\mathrm{db} / \mathrm{db} \text { mice, } \mathrm{Mdr} 2^{-/-} \text {mice }\end{array}$ & IL-6/STAT3 & $(49)$ \\
\hline & $\begin{array}{l}\text { R26Tom Hnflb }{ }^{\text {CreER }} \text { transgenic mice } \\
\text { DEN, Mdr2 }{ }^{-/-} \text {mice }\end{array}$ & N/A & $(50)$ \\
\hline & 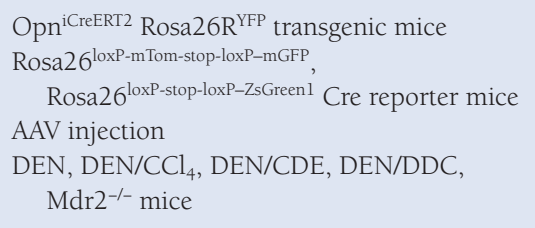 & N/A & $(51)$ \\
\hline & $\begin{array}{l}\text { Alfp }{ }^{\mathrm{Cre}} \mathrm{p}^{53^{\mathrm{I} / \mathrm{I}}} \\
\text { hydrodynamic tail-vein injection }\end{array}$ & YAP, Wnt & $(52)$ \\
\hline & $\begin{array}{l}\text { Foxl1 }{ }^{\text {Cre }} \text { Rosa26R } \\
\text { Rosa2 } 26^{\text {loxP-stop-loxP-YFP }} \text { Cre reporter mice } \\
\text { AAV injection } \\
\text { DEN/CCl }\end{array}$ & YAP & $(53)$ \\
\hline & $\begin{array}{l}\text { SOX9IRES CreERT2 Rosa26R }{ }^{\mathrm{YFP}} \\
\quad \text { serum albumin }(\mathrm{SA})^{\text {CreERT2 }} \text { Rosa26R } \\
\text { transgenic mice } \\
\text { hURI-tetOFFhep mice }\end{array}$ & $\begin{array}{l}\text { galectin-3, } \\
\alpha \text {-ketoglutarate }\end{array}$ & $(54)$ \\
\hline
\end{tabular}


suppressor gene neurofibromatosis type 2 (Nf2) in livers of developing or adult mice resulted in liver cancer formation that was preceded by a progressive expansion of progenitor cells while differentiated hepatocytes were not affected (37).

Notch signaling, activated in one-third of human HCCs, was shown to promote liver carcinogenesis in a genetically engineered mouse model (38). All Notch-induced tumors showed various degrees of nuclear staining for the Notch target gene SOX9, a marker of HPCs (39); and SOX9 overexpression was frequently observed in human HCCs. Therefore, during hepatocarcinogenesis, Notch may either control the expansion of a pre-existing progenitor-like cell population or drive progenitor-like properties to differentiated cells (Figure 1).

Furthermore, somatic $\beta$-catenin stabilization in a unique population of progenitor cells in fetal liver resulted in the frequent development of HCCs with spontaneous lung metastases (40). Interestingly, this is in striking contrast to the absence of tumors when $\beta$-catenin is stabilized in adult hepatocytes indicating that activation of the Wnt pathway alone is insufficient for HCC initiation. Indeed, additional introduction of genetic alterations such as oncogenic Ha-rat sarcoma (Ras) or Akt mutation does result in cancer formation $(41,42)$.

Mice with proliferation-deficient hepatocytes spontaneously developed hepatic tumors composed of cells with CSC characteristics, including the capacity for self-renewal, differentiation, and tumorigenesis, due to prolonged necrotic regenerative cycles combined with oncogenic signal transducer and activator of transcription (STAT) 3 activation (43). The highly proliferating cancerous cells in this model can only be derived from HPCs that are still capable of proliferation and differentiation.

The investigations of hepatocarcinogenesis in different rat models additionally point towards HPCs as a potential cell of origin of HCC. Comprehensive characterization of the neoplastic development, by exploring the expression of the biliary and HPC marker cytokeratin (CK) 19 during the evolution of early preneoplastic lesions to fully developed HCC, suggested the potential progenitor derivation of the majority of the developed tumors (44). Additionally, global gene expression analysis revealed that CK19 may serve as a prognostic marker of early persistent hepatic preneoplastic lesions. Moreover, a CK19-associated gene signature discovered through comparative functional genomics robustly stratified HCC patients according to clinical outcome, highlighting the strength of this rat model to reproduce stem cell/progenitor cell-derived human HCC (44). Subsequently, a subpopulation of precancerous cells in another rat liver carcinogenesis model was identified, which were enriched in $\mathrm{CD} 133{ }^{+} \mathrm{CD} 44^{+}$cells that formed part of the HPC fraction (45).

Finally, a recent lineage-tracing analysis showed that HPCs activated in chronically damaged liver and thought to originate from proliferating ductal cells were specifically labeled in epithelial cell adhesion molecule (EpCAM) CreERT2 mice and gave rise to HCCs through the accumulation of induced genetic alterations, supporting the existence of progenitor-derived hepatocarcinogenesis (46).

\section{Hepatocytes as the cellular origin of HCC}

More recent studies highlight adult hepatocytes as the other main source of HCCs (Figure 1, Table 1). These cells have the potential to directly transform into cancer cells following sequential genomic damage and dedifferentiate into precursor cells 
expressing markers of progenitor cells (47). It was shown that hepatocyte-specific p62 expression promotes c-MYC induction, mechanistic target of rapamycin (mTORC) 1 activation, and HCC initiation (48). Another investigation demonstrated that mice overexpressing FGF19 in hepatocytes develop HCC (49). Moreover, activation of STAT3 signaling through induced IL-6 production in the hepatic microenvironment was shown to be essential for FGF19-induced tumorigenesis. Both studies demonstrate that genetic targeting of hepatocytes promotes development of liver cancer in mice.

In contrast to the lineage-tracing analysis employing EpCAMCreERT2 mice described above, studies using various other fate-tracing systems have shown that in hepatotoxin-induced as well as in carcinogen-free models, HCC does not originate from progenitor cells, thereby clearly demonstrating that tumors arose from hepatocytes in the liver. Tracking of progenitor cells via their expression of the biliary marker hepatocyte nuclear factor (HNF) $1 \beta$ provided the first clear evidence that tumors in classical genotoxic or genetic mouse HCC models do not originate from HPCs (50), at least in these experimental animal models. Consecutively, complementary fate-tracing approaches were employed to label the progenitor compartment and hepatocytes in murine hepatocarcinogenesis in order to not only rule out that HPCs represent the cell of origin of HCC but also prove that indeed hepatocytes bear the TICs. Tracking HPCs through osteopontin (Opn)-CreERT2 and genetically labeling of hepatocytes via infection with adenoassociated viral serotype 8 (AAV8)-thyroxine binding globulin (Tbg)-Cre suggested that hepatocytes constitute the main cellular source of HCC in mice and that a progenitor signature may not reflect progenitor origin, but dedifferentiation of hepatocyte-derived tumor cells (51). Indeed, loss of p53 facilitated YAPinduced tumorigenesis. Mature hepatocytes dedifferentiated into nestin-positive progenitor-like cells, followed by differentiation into HCCs in response to mutations targeting Wnt (52). Utilizing a complementary strategy to label the HPC compartment, Forkhead box Ll (Foxll)+ cells, which express the progenitor markers EpCAM, SOX9, and CD133, were shown to not contribute to HCC tumorigenesis (53). Here, tumors arose exclusively from hepatocytes. Using human data as well as mouse models of HCC, HPCs were shown to be activated and expanded by transformed hepatocytes through galectin-3, maintaining HPC stemness, and $\alpha$-ketoglutarate, preserving an HPC undifferentiated state (54). In the human unconventional prefoldin RPB5 interactor (hURI)-tetOFFhep mouse model, both hepatocytes and HPCs contributed to tumor heterogeneity. However, HCC predominantly originated from hepatocytes, whereas benign lesions developed from HPCs (54). Of note, HPCs are mainly activated and start to proliferate in damaged livers where hepatocyte proliferation is compromised (55). Most experimental conditions often do not actively suppress the ability of hepatocytes to proliferate and may therefore not always reflect the diverse human settings, which may well favor HPC proliferation due to local hepatocyte inhibition.

\section{LIVER CANCER STEM CELLS}

The observation that tumors exhibit significant cellular heterogeneity with respect to their tumorigenic potential led to the CSC concept (56). This concept proposes that the growth of tumors is fuelled by limited numbers of dedicated stem cells 
that are capable of unlimited self-renewal and production of heterogeneous progeny (57). CSCs are considered to be highly tumorigenic, metastatic, chemotherapy- and radiation-resistant, and responsible for tumor relapse (58). Indeed, the participation of liver cancer stem cells (LCSCs) in hepatocarcinogenesis was reported. Initial studies were based on the identification of a side population (SP) in HCC cell lines and tumors after staining with the DNA-binding dye Hoechst 33342 that was enriched in cells displaying CSC properties $(59,60)$. Interestingly, when DEN-induced collagenase-resistant aggregates were isolated and characterized, cells were detected that can give rise to HCC only after transplantation into an appropriate host liver undergoing chronic injury (61). These HCC progenitor cells (HcPCs) acquired autocrine IL-6 signaling that stimulated their in vivo growth and malignant progression. Ectopic lymphoid structures (ELS), associated with chronic nuclear factor "kappa-light-chain-enhancer" of activated B-cells (NF-kB) activation, were shown to function as cytokine-rich microniches for these tumor progenitor cells (62).

Subsequent investigations focused on the attempt to identify and use reliable membrane marker(s) for LCSCs. In the following sections, we will discuss accepted markers and the need to define a consistent combination of them that can be utilized to clearly define this heterogeneous cell type, summarize important signaling pathways that govern their stemness, and describe state-of-the-art assays to isolate and evaluate CSCs.

\section{Markers to identify LCSCs}

CD133, also referred to as prominin-1, is a well-established cell surface marker of hematopoietic stem cells, neuronal stem cells, and HPCs (63). In HCC, its presence seems to be of clinical significance, since patients with high CD133 expression exhibit poor overall survival and higher recurrence rates compared with patients with low CD133 expression (64). A meta-analysis of all the data available in the literature about the correlation between CD133 expression and various clinicopathological parameters revealed that the abundance of CD133 expression correlated with enhanced alpha-fetoprotein levels, a poor histological grade and survival, but did not show significant relation with hepatitis, cirrhosis, and stage of the tumor (65).

Moreover, CD133 was identified as a LCSC marker. Initial studies were based on the identification and characterization of $\mathrm{CD} 133^{+}$cells in hepatocarcinoma cell lines. In $\mathrm{CD}_{133^{+}}$cells, when compared to their $\mathrm{CD} 133^{-}$counterpart, a greater colony-forming capacity in vitro and higher proliferative activity as well as enhanced ability to form tumors in vivo, both in orthotopic and subcutaneous cancer models, was seen (66-68). CD133+ cells preferentially expressed genes associated with stemness, such as Bmil, SOX2, Oct4, Notch, Nanog, Nestin, and membrane transporters ATP-binding cassette (ABC) G2 and ABCB1 (68). Subsequent studies focused on the characterization of $\mathrm{CD}_{133^{+}}$cells in primary human hepatocarcinomas. CD133 expression in HCC was associated with an advanced tumor stage, a larger tumor size, and a poor prognosis (69). A rare CD133 population in HCC specimens, with expression ranging from 1.3 to $13.6 \%$ of the total tumor cell population, was identified (69). When isolated, these cells were able to form tumor spheroids composed of undifferentiated tumor cells and 
had a larger capacity to grow tumors of identical morphology compared to the parental ones in immunodeficient mice (69). Interestingly, overexpression of miR130b, an miR targeting p53-induced nuclear protein 1 (TP53/NP1), was detected in $\mathrm{CD} 133^{+}$cells. To further characterize these cells on a molecular level, CD133+ and $\mathrm{CD} 133^{-}$cells were isolated from both tumor cell lines and primary tumor samples and characterized by genome-wide expression analysis. Self-renewal, tumorigenesis, and angiogenesis were shown to be promoted by $\mathrm{CD} 133^{+}$liver TICs through neurotensin-induced activation of the IL-8 and chemokine (C-X-C motif) ligand 1 (CXCL1) signaling cascade (70).

CD44, a major adhesion molecule of the extracellular matrix and the receptor for hyaluronic acid, is implicated in a wide range of biological processes. CD44 potentiates AKT activation, thereby ceasing the p53 genomic surveillance response. DNA-damaged hepatocytes thus escape p53-induced death and senescence and respond to proliferative signals, promoting the accumulation of mutations and subsequently transformation to HCC progenitors (71). In HCC, the expression of CD44s (CD44 standard variant) was related to TGF 3 -mediated regulation of the mesenchymal phenotype, and a negative patient prognosis was associated with overexpressed levels of CD44s (72). CD44s was recently shown to play an important role in maintaining CSCs and regulating oxidative stress of an HCC cell line in a Notch3-dependent manner. In addition, CD44 expression in HCC tissues was significantly correlated with Notch3 expression, further strengthening the idea that CD44 regulates CSC properties via Notch3 (73). In an effort to investigate interactions between the tumor microenvironment and CSCs, IL-6 produced by tumor-associated macrophages (TAMs) was shown to promote expansion and tumorigenesis of CD44+ cells. Concomitantly, levels of IL- 6 in human HCC samples positively correlated with tumor stage and markers of CSCs (74)

In a separate study, CD44 was preferentially expressed in the $\mathrm{CD} 133^{+}$population, and double-positive cells possessed the abilities of extensive proliferation, self-renewal, and differentiation. Furthermore, double-positive cells expressed more stem cell-associated markers, such as Bmil, rendering them highly tumorigenic and chemoresistant (75). Moreover, $\mathrm{CD} 133^{+} \mathrm{CD} 44^{\text {high }}$ cells played a key role in hematogenous metastasis of liver cancers, with CD133 being responsible for tumor growth and CD44 being important for invasion (76). In human patients, $\mathrm{CD}_{4} 4^{+}$and $\mathrm{CD}_{3} 33^{+}$correlated with increased risk of poorly differentiated HCC and elevated alpha-fetoprotein levels. CD44 and CD133, alone or in combination with microvascular invasion, are independent predictors of poor prognosis in patients undergoing transplantation for HCC (77).

Expression levels of CD24, a mucin-like cell surface glycoprotein, are related to liver cancer progression and prognosis (78). Additionally, it was recently identified as a potential marker of LCSCs. CD24+ HCC cells were found to be critical for the maintenance, self-renewal, differentiation, and metastasis of tumors through STAT3-mediated Nanog upregulation, and to significantly impact patients' clinical outcome. CD24 expression overlaps with that of CD133 and EpCAM (79). CD24 expression on hepatocarcinoma cells was shown to be induced by Twist2 and to be required for the stimulation of HCC stem cell self-renewal (80). Most recently, an investigation of the regulation of CSCs by the tumor microenvironment demonstrated that HGF and IL-6 secreted by cancer-associated fibroblasts promoted self-renewal, chemotherapy resistance, metastasis, and tumorigenicity 
of $\mathrm{CD} 24^{+}$cells. More precisely, regulation of stemness properties was dependent on STAT3 signaling (81). The abundance of the stem cell markers CD24 and CD133 in tumors of HCC patients correlated with increased inducible nitric oxide synthase (iNOS) expression, promoting Notchl signaling and subsequent development of stemness traits, as well as accelerated HCC initiation in the mouse xenograft tumor model (82).

EpCAM, a homophilic, Ca2+-independent cell-cell adhesion molecule, is expressed on a subset of normal epithelia and overexpressed on malignant cells derived from a variety of tumors. This overexpression is even more pronounced on TICs (83). HCCs can be subdivided into two different subgroups, with EpCAM+ tumors displaying features typically observed at the level of HPCs and EPCAMhepatocarcinomas exhibiting features more typical of mature hepatocytes (24). EpCAM expression was induced by Wnt- $\beta$-catenin (84). Moreover, zinc finger protein X-linked was shown to activate and maintain EpCAM+ liver CSCs by promoting nuclear translocation and transactivation of $\beta$-catenin (85). EpCAM ${ }^{+}$cells isolated from $\mathrm{EpCAM}^{+} \mathrm{AFP}^{+} \mathrm{HCCs}$ displayed properties of CSCs and were able to initiate tumorigenesis when inoculated into immunodeficient mice $(86,87)$. The highest tumor-initiating activity in hepatocarcinoma cell lines was found

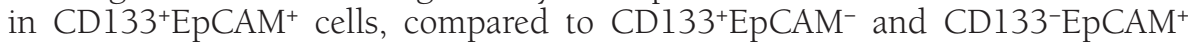
populations (88).

CD90, a glycosylphosphatidylinositol-anchored glycoprotein, also known as Thy-1, was revealed to be a reliable marker for CSCs. The number of $\mathrm{CD} 90^{+}$cells isolated from different HCC cell lines positively correlated with tumorigenicity and metastatic potential. $\mathrm{CD} 45^{-} \mathrm{CD} 90^{+}$cells, in contrast to $\mathrm{CD} 90^{-}$or $\mathrm{CD} 45^{-} \mathrm{CD} 90^{-}$cells, isolated from tumor tissues and blood samples of liver cancer patients had the capacity to generate tumor nodules in immunodeficient mice $(89,90)$. Interestingly, CD44 was shown to regulate the survival and the tumorigenic activity of $\mathrm{CD} 90^{+}$ liver cancer cells. $\mathrm{CD} 90^{+} \mathrm{CD} 44^{+}$cells showed a more aggressive phenotype than the CD90 ${ }^{+} \mathrm{CD} 44^{-}$counterpart (90). In primary HCC, EpCAM and CD90 expressions were mutually exclusive. Gene-expression analysis of sorted cells suggested that $\mathrm{EpCAM}^{+}$cells exhibited features of epithelial cells, whereas $\mathrm{CD} 90^{+}$cells resembled mesenchymal cells (91). A poorly differentiated morphology and high serum alphafetoprotein was associated with the presence of $\mathrm{EpCAM}^{+}$cells, whereas a high incidence of distant organ metastasis correlated with CD90 positivity (91). Most interestingly, a potential interaction of $\mathrm{EpCAM}^{+}$and $\mathrm{CD} 90^{+} \mathrm{CSCs}$ was demonstrated. The motility of $\mathrm{EpCAM}^{+}$cells was enhanced by $\mathrm{CD} \mathrm{O}^{+}$cells when cocultured in vitro through the activation of TGF $\beta$ signaling (91). CyclinDl overexpression and subsequent Smad signaling increased the development of the $\mathrm{CD} 90^{+} \mathrm{EpCAM}^{+}$cell population, concomitantly increasing stemness and chemoresistance (92). Studying gene expression differences between $\mathrm{CD} 90^{+} \mathrm{CSC}$ f from tumor tissue and $\mathrm{CD} 90^{+}$ cells from non-tumorous counterparts confirmed the upregulation of genes in $\mathrm{CD} 0^{+} \mathrm{CSC}$ associated with the biological processes of liver inflammation, chemoresistance, and lipid metabolism (93).

Enrichment of CD13, a membranous glycoprotein, was correlated with early recurrences and poor prognosis in patients with HCC (94). It was identified as a marker for semi-quiescent CSCs in human liver cancer cell lines and clinical samples $(95,96)$. The association of $\mathrm{CD}^{3} 3^{+} \mathrm{CSC}$ with a hypoxic marker in clinical HCC samples points to a critical role of these cells in carcinogenesis and resistance to therapy in liver cancers (97). In liver cancer cells, increased CD13 
expression was associated with TGF $\beta$-induced epithelial to mesenchymal transition (EMT), concurrently preventing further increases of both reactive oxygen species levels and the induction of apoptosis, thereby promoting the survival of CD13+ cells (98).

OV6, a monoclonal antibody isolated from carcinogen-treated rat liver, was shown to serve as a hepatic progenitor marker (99). Interestingly, the expression of this molecule defined a subpopulation of less differentiated progenitor-like cells in both HCC cell lines and primary HCC tissues (100). These cells exhibited endogenously active $\mathrm{Wnt} / \beta$-catenin signaling, enhanced tumorigenicity in vivo, and a substantial resistance to standard chemotherapy (100). CSC-like HPC lines overexpressing OV6 as well as CD133, EpCAM, and the pluripotency factor Oct4 can be established from human non-tumorous, tumor-surrounding tissue (101). Moreover, OV6-positive TICs were more invasive and metastatic both in vitro and in vivo and expressed high levels of C-X-C chemokine receptor type 4 (CXCR4), indicating a role for SDF-1/CXCR4 signaling in sustaining stem cell properties (102). Patients with elevated numbers of $\mathrm{OV}^{+}$tumor cells were associated with aggressive clinicopathologic features and poor prognosis (102).

\section{Marker combinations to clearly define LCSCs}

As discussed above, several LCSC markers have been reported and used to isolate and characterize LCSCs (Figure 1). However, the reliability of each of these markers in identifying true LCSCs is still controversial (103) calling for a comprehensive evaluation of the effectiveness of stem cell markers. In an effort to evaluate the efficiency of some markers to characterize and isolate LCSCs, a range of the most commonly used ones (CD44, CD90, and CD133) were tested in both human HCC samples and HCC cell lines. Surprisingly, CSC markers were present in both tumors and adjacent non-cancerous liver. However, the number as well as the staining intensity of positive cells varied with no consistent expression patterns (104). Furthermore, LCSCs isolated from the same cell line via different markers or from different cell lines via the same markers exhibited a unique genetic program of gene expression reflecting the strong heterogeneity of the origin of liver cancer and possibly the varied etiology of HCC (104). On the contrary, a more recent study demonstrated that increased expression of a combination of markers (CD90, CD24, CD13, and CD133) in HCC not only correlated with advanced disease stage but also with larger tumor size and worse overall survival (105). The markers CD90, CD44, CD133, CD13, and CD24 were present diversely in all HCC samples. In contrast to the previous study, their expression in non-tumor liver tissues was almost absent (105). CD $90^{+} \mathrm{CD} 24^{+} \mathrm{CD} 13^{+} \mathrm{CD} 133^{+}$ HCC cells possessed progressively increasing self-renewal and tumor-initiating ability in vitro and in vivo (105).

Combining more than one marker has been shown to increase the isolation efficiency $(75,103)$. LCSCs most probably represent a large group of diverse subtypes, each expressing their own different combination of markers. To develop future therapies targeting CSCs, and to predict prognosis and efficacy of these therapies, it is therefore crucial to comprehensively study and define these distinct groups of CSCs in relation to their expression profiles and clinicopathologic features of HCC. 


\section{Signaling pathways governing stemness of LCSCs}

Several signaling cascades in LCSCs are important to regulate their capacity of unlimited self-renewal and production of heterogeneous progeny, their tumorigenic and metastatic potentials, as well as their resistance to chemotherapy and radiation (Figure 1). The essential pathways are Wnt/ $\beta$-catenin, Notch, and TGF $\beta$, among others (106).

Wnt/B-catenin activation is one of the pathways being aberrantly active in HCC (107). Proliferation, rapid generation of tumor spheres, and high invasiveness of SP cells isolated from liver cancer samples depended on Wnt/ $\beta$-catenin signaling (108). In this group of liver cancer cells, elevated expression of $\beta$-catenin leads to an increased expression of $\mathrm{Wnt} / \beta$-catenin target genes, including AXIN2, DKK1, and CCND1 (108). Importantly, activation of Wnt/ $\beta$-catenin signaling has been reported in $\mathrm{CD}_{3} 33^{+}(68), \mathrm{EpCAM}^{+}(86)$, and $\mathrm{OV}^{+}(100) \mathrm{CSC}$. The Wnt pathway is activated following nuclear translocation of the $\beta$-catenin component, thereby inducing the transcription of prominent targets, such as CD44 (109), EpCAM (84), and c-Myc (110).

Notch signaling misregulation in liver cancer has been described as both oncogenic and tumor-suppressive, depending on the cellular context (111). This pathway was activated in $\mathrm{CD} 90^{+}$cells isolated from HCC cell lines and was associated with self-renewal, invasion, migration and expression of stem cell-related genes (112). Notch signaling stimulated G1-S transition in the cell cycle phase and inhibited apoptosis, thus facilitating CSC features (112). $\mathrm{CD} 90^{+} \mathrm{CD} 24^{+} \mathrm{CD} 13^{+}$ CD133+ HCC cells utilize upregulation of Notch and Wnt/ $\beta$-catenin to initiate tumor growth and self-renewal (105).

Activation of the sonic hedgehog (Shh) pathway occurs in the $\mathrm{CD} 133^{+}$subpopulation of Hepa 1-6 cells that harbor stem cell features (113). In general, Hh-Notch interactions were shown to regulate cell-fate decisions in an HPC-like cholangiocyte cell line (114).

TGF $\beta$ serves as a central regulator of signal transduction during inflammation and HCC (115). Recently, TGF $\beta$ signaling has also been linked to the malignant transformation of LCSCs. The percentage of SP cells, as well as their survival rate and chemotherapeutic resistance, was shown to increase following TGF $\beta$ treatment of a hepatoma cell line. Gene analysis revealed that epidermal growth factor receptor (EGFR) was upregulated and that this was dependent on Smad (116). On the contrary, TGF $\beta$ treatment resulted in decreased cell survival and concomitantly a reduced number of SP cells in HCC cell lines through induction of accumulation of cells at G0/G1 and upregulation of p-c-Jun N-terminal kinases (JNK), p-c-Jun, and p-Smad2 expression(117). These recent results indicated that TGF $\beta$ has anticancer effects mediated by inhibition of CSC survival. Differences in the analyzed cell lines and assays most probably account for the diverse outcomes. Nevertheless, both studies emphasize the diverse and controversial functions of TGF $\beta$ signaling in LCSCs. CD133 expression was upregulated by TGF $\beta 1$ stimulation through epigenetic regulation of promoter methylation. Furthermore, increased tumorigenicity of TGF $\beta 1$-induced CD133+ cells compared to CD133- cells was shown (118). A change in the expression pattern of stem cell genes, enhancement of their stemness potential, and migratory and invasive capacity was observed in HCC cells, mediated by TGF $\beta$ induced EMT (119). Similarly, HIFl $\alpha$-induced EMT, by activation of the Notchl 
pathway through direct interaction with Notch intracellular domain, promoted the CSC characteristics of HCC cells (120). When investigating the tumor microenvironment, TAMs were found to secrete TGF $\beta 1$ that promoted CSC-like properties through EMT induction (121).

Both HCC cell lines and HCC patient samples were shown to exhibit expression of at least one key driver of embryonic development such as Oct4, Nanog, SOX2, and STAT3 accompanied by the expression of genes of the $\mathrm{Wnt} / \beta$-catenin and TGF $\beta$ families (122). Highly enriched CSC populations isolated from different liver cancer cell lines maintained a common gene expression signature characteristic of cellular stemness and harbor an activation of NF-KB as well as IL-6 and $\mathrm{Wnt} / \beta$-catenin signaling pathways. Each individual cell line typically exhibited an activation of unique oncogenic pathways such as EGFR, MYC, and SRC, which are known to be associated with HCC (123).

\section{Isolation of LCSCs}

Currently, identification and isolation of LCSCs is achieved through several approaches, including (i) detection of SP by the Hoechst 33342 exclusion assay (59), (ii) separation using surface markers (124), and (iii) in vitro tumor sphere formation $(125,126)$. SP cells can be detected and isolated by flow cytometry through their ability to efflux Hoechst 33342 dye through an adenosine triphosphate (ATP)-binding cassette (ABC) membrane transporter. Overexpression of $\mathrm{ABC}$ proteins was associated with CSCs, conferring drug resistance to them (127). SP cells purified from HCC cells were shown to harbor CSC-like properties (59). However, some restrictions are associated with this isolation approach, since the SP compartment contains both stem and non-stem cells, and, on the other hand, other stem cells of ill-defined identity are not found in the SP fraction (128). Interestingly, epigenetic modulation increased the frequency of cells with CSC properties in the SP fraction isolated from human cancer cells, facilitating functional isolation of cells, which possess self-renewal and tumor-initiating capacity (123).

LCSCs are commonly isolated from cell cultures or whole liver by fluorescent (or magnetic) activated cell sorting using surface markers reported to be specific for CSCs of HCC. As already discussed above, the heterogeneity and complex nature of CSC biology hamper the reliable use of single-or even combinations of-markers to draw reproducible conclusions.

Sphere cultures have been used as a method for the enrichment of stem cells relying on their property of anchorage-independent growth. The tumor sphereforming cells derived from human hepatoma cell lines were capable of proliferation and self-renewal, and possess higher tumorigenicity and a general resistance to chemotherapeutics (126). Using this approach may favor the selection of a specific subpopulation of CSCs during cultivation.

The different ways to isolate LCSCs all have their limitations, and therefore, caution has to be taken when comparing results obtained with dissimilar approaches. In the future, improved knowledge of the diversity of LCSCs will allow to define and selectively isolate these cells. CSC-specific properties, that is, unlimited self-renewal, ability to develop a malignant tumor, and resistance to chemotherapeutic agents, can be evaluated by some assays in vitro and in vivo. 


\section{Characterization of LCSCs}

The clonogenic or colony formation assay represents an in vitro cell assay based on cell survival and the ability of an individual cell to grow into a colony, thereby testing for the ability to divide an unlimited number of times (129). This assay can provide information about cell survival and resistance after treatment with different agents. However, this assay does have limitations such as the loss of the threedimensional environment of a cell within a given tissue. Therefore, the effect of cell-cell or matrix-cell communication on cell proliferation cannot be measured. Moreover, this assay cannot be used in case the substance concentration decreases cell growth but does not affect cell cycle progression and/or DNA synthesis (130).

The ability to form spheres is used to enrich CSCs and can additionally also be applied as an in vitro method for assessing the self-renewal and multipotency capacity of a given cell population. Three-dimensional spheroids can be formed by CSCs containing a heterogeneous population of progenitor cells, which can differentiate into multiple cell types under these low-adherence and nondifferentiating conditions. The ability of cells to form tumor spheres upon multiple passages demonstrates the self-renewal capacity of CSCs, and this potential correlates with the number of spheres formed (106). Hypoxia and the low pH in the sphere's core and the characteristics of the inner cells that may be inaccessible to metabolites and drugs in comparison to exterior cells are believed to mimic the characteristics of solid tumors in vivo. Moreover, this assay has been used to evaluate the migration and invasive ability of CSCs. Even though self-renewal of CSCs can be usefully assessed by this assay, several limitations have to be acknowledged (131). The size of generated spheres and the number of cells that are necessary to form spheres strongly depend on the cell type and methodology used. This makes the comparison of results from different cell types challenging (132).

In an in vivo tumorigenicity assay, the tumor cell population of interest is transplanted into animal models, followed by an evaluation of their tumorpropagating capacity (133). Nevertheless, this assay has some limitations. This relates to the use of immunodeficient animals and the fact that the context of tumor development is clearly different from recipient animals harboring a normal immune system. Additionally, it is important to consider that upon xenotransplantation, the architecture and stroma of the tumor differ compared with its native niche. Finally, if the cells used for transplantation are isolated based on a selection of markers, the effects of the total population can be lost. Some of these constraints can be circumvented by using syngeneic models, by injecting the cells orthotopically, or by analyzing different subpopulations simultaneously with the total population, although this is not always possible. The transplantation assay is the current "gold standard" for identifying CSCs because it can assess both selfrenewal and multipotency. On the other hand, lineage tracing is the current gold standard for defining the cell of origin of transformation in mouse models. However, it is also being applied to elucidate the proliferative potential and fate of stem cells (125). Different cell-specific promoters allow distinct cell subpopulations to be labeled, facilitating tracking of a single cell-derived clone in animals. Lineage tracing utilizes (in some cases inducible) Cre transgenic mouse lines, harboring cell type-specific gene promoters to drive Cre expression, and common reporter lines, either fluorogenically or colorigenically flanked by a loxP-STOPloxP sequence. Cre expression via excising loxP-STOP-loxP cassettes activates the 
reporter in cells that possess the respective promoter activity. As with other assays, there are limitations associated with lineage tracing as well. Labeling efficiencies are highly variable depending on the Cre- or reporter-driving promoters. Systems frequently become "leaky," having minor but detectable Cre activity in the absence of the inducer, resulting in spontaneous background recombination. One of the main limitations is the fact that CSCs or HPCs are a particular heterogeneous population that may switch phenotype and marker expression (134) in a contextdependent manner. Therefore, lineage tracing of these cells focuses on a certain subpopulation only. Nevertheless, when carefully considering all potential pitfalls, this assay presents a valuable tool to obtain a better understanding of the cellular origins of cancer and CSCs (125). Although in vitro assays are convenient and faster, until now, the best assay to reliably and robustly assess tumorigenicity has been in vivo evaluation.

\section{THERAPEUTIC RESISTANCE OF LCSCS}

The effectiveness of standard therapies against HCC, such as chemotherapy, the multikinase inhibitor sorafenib, and radiotherapy, is impaired by LCSC-mediated resistance (135) (Table 2). Cellular quiescence, DNA repair capacity, and ABCtransporter expression are characteristics of CSCs mediating chemo- or radiotherapy resistance and regrowth of the tumor after treatment (128). The increased expression of stem cell surface proteins in liver cancer SP cells induced the rapid formation of tumor spheres and enhanced transcription of drug efflux genes (ABCG2, MDR1, and ABCB5). These cells were resistant to numerous DNA targeting drugs (108). CD133+ HCC cells contributed to chemoresistance through preferential activation of Akt/PKB and Bcl-2 cell survival response, thereby supporting the opinion that CSCs are the source of tumor recurrence after chemotherapy (136). Additionally, these cells were more resistant to radiation-induced apoptosis than CD133- cells and exhibited greater proliferation and tumor-initiating capacity in vivo post-radiation (137). Downmodulation of this membrane antigen in isolated cells induced both a decrease in their stemness properties and an enhancement in their chemo- and radiosensitivity, at least to some extent, indicating that resistance of CD133+ liver CSCs is related to CD133 expression (138). An enrichment of $\mathrm{CD}^{+} 0^{+}$and $\mathrm{CD} 133^{+}$cells was observed in tumor spheres obtained from the culture of HCC cell lines under serum-free conditions favoring stem cell growth. These spheres showed a high overexpression of ABCG2 and Oct4 and resistance to chemotherapy drugs (127). Expression of CD13 was shown to reduce the extent of DNA damage induced by the production of reactive oxygen species following genotoxic stress, thereby protecting cells from apoptosis, and thus rendering cells radio- and chemoresistant $(95,96)$.

In a study that focused on exploring whether CSC markers have a predictive role with regard to the sorafenib response in HCC patients, overexpression of CD133 and CD90 in HCC was associated with a worse response to the multikinase inhibitor and therefore a shorter progression-free survival time (139). Sorafenib-resistant HCC tumor cells show a high expression of CD24. The requirement for resistance to sorafenib of this functional marker relied on AKT/ mTOR-mediated autophagy regulation (78). 


\section{TABLE 2 Therapeutic resistance in LCSCs}

\begin{tabular}{|c|c|c|c|}
\hline LCSC marker & Resistance & Mechanisms & Reference \\
\hline \multirow[t]{3}{*}{ Side population cells } & $\begin{array}{l}\text { 5-FU, gemcitabine, oxaliplatin, paclitaxel, } \\
\text { cisplatin, etoposide, oxaliplatin }\end{array}$ & $\begin{array}{l}\text { ABCG2, MDR1, } \\
\text { ABCB5 }\end{array}$ & (108) \\
\hline & $5-\mathrm{FU}$ & TGF $\beta / S m a d / E G F R$ & (116) \\
\hline & Sorafenib & AKT, ERK & (142) \\
\hline \multirow[t]{4}{*}{ CD133 } & Doxorubicin, fluorouracil & Akt/PKB & (136) \\
\hline & Radiation & MAPK/PI3K & (137) \\
\hline & Cisplatin, doxorubicin, radiation & $\mathrm{Bcl}-2 / \mathrm{Bax}$ & (138) \\
\hline & Sorafenib & ABCG2 & (168) \\
\hline CD133, ЕрСAM & Doxorubicin & N/A & (88) \\
\hline \multirow[t]{2}{*}{ CD133, CD90 } & Doxorubicin & Oct 4, ABCG2 & (127) \\
\hline & Sorafenib & N/A & (139) \\
\hline CD133, CD44 & Sorafenib & $\mathrm{ABCCl}-3$ & $(140)$ \\
\hline \multirow[t]{3}{*}{ CD24 } & Sorafenib & AKT/mTOR & (78) \\
\hline & Cisplatin & STAT3/Nanog & (79) \\
\hline & Sorafenib & STAT3 & (81) \\
\hline CD90 & Doxorubicin & PI3K/Aktl & (169) \\
\hline CD90, ЕрСAM & Cisplatin, doxorubicin & cyclin Dl/Smad & (92) \\
\hline EрCAM & Sorafenib & TSC2/AKT & $(141)$ \\
\hline $\mathrm{CD} 13$ & 5-FU, doxorubicin, radiation & N/A & $(95-97)$ \\
\hline OV6 & Cisplatin & Wnt $/ \beta$-catenin & $(100)$ \\
\hline Sphere-forming cells & $\begin{array}{l}\text { Cisplatin, 5-FU, gemcitabine, mitomycin, } \\
\text { sorafenib }\end{array}$ & N/A & (126) \\
\hline $\begin{array}{l}\text { Chemo-resistant } \\
\text { cells }\end{array}$ & 5-FU, cisplatin, doxorubicin & Oct4/AKT/ABCG2 & (170) \\
\hline
\end{tabular}

Enriched proportions of $\mathrm{CD}_{4} 4^{+}$and $\mathrm{CD} 44^{+} \mathrm{CD} 133^{+} \mathrm{HCC}$ cells in sorafenibresistant cells, as well as upregulation of stemness genes Nanog, SOX2, and Oct4 in EpCAM-positive HCC cells and enhancement of tumorigenicity after treatment with sorafenib $(140,141)$, further suggest that sorafenib can foster cancer stemness in liver cancer. A subpopulation of CSCs derived from HCC cell lines, referred to as label-retaining cancer cells that are distinguished by pluripotency gene expression profile, were shown to possess a relative resistance to sorafenib. Treatment of these CSCs led to reduced apoptosis and improved viability and was accompanied by gene expression profiles, which mark stem cell differentiation (142). All results emphasize the role of sorafenib treatment in CSC maintenance and CSC-mediated resistance against sorafenib. 


\section{CLINICAL IMPLICATIONS OF LCSCS}

The important role of LCSCs in the initiation, maintenance, relapse, metastasis, and drug resistance of HCC has been identified. Therefore, development of novel liver cancer diagnosis and treatment strategies will be impacted by the identification of signaling pathways as well as stem cell markers activated in LCSCs (58). Targeting LCSCs is expected to be a promising approach for the treatment of liver cancer (143).

HCC patients with stemness-associated gene expression traits generally have a poor prognosis $(23,24,123,144,145)$. However, predictive values of single LCSC markers still remain controversial (146). Rather, a combination of several markers may provide greater specificity and reliability in predicting HCC prognosis $(24,147)$. CSCs can be isolated from peripheral blood mononuclear cells as circulating tumor cells due to their highly invasive and metastatic capacity and thus may provide diagnostic or prognostic information $(89,148)$.

In recent years, targeting LCSCs has become a novel strategy to improve the outcome of HCC treatment. Targeted therapies based on tumor cell-specific cell surface markers have been proposed to specifically eradicate LCSCs (149). Anti-CD133 antibody-drug conjugates inhibited CD133+ HCC growth in vitro and in vivo (150). Similarly, CD44 blockade prevented the formation of local and metastatic tumor nodules by the $\mathrm{CD} 0^{+}$cells (90), and EpCAM blockage via RNA interference significantly inhibited cellular invasion, spheroid formation, and tumorigenicity of an HCC cell line (86). Additionally, it was shown that the combination of a CD13 inhibitor and the genotoxic chemotherapeutic fluorouracil (5-FU) reduced tumor volume compared with either agent alone. 5-FU inhibited $\mathrm{CD} 0^{+}$proliferating CSCs, some of which produced CD13 $3^{+}$semiquiescent CSCs, while CD13 inhibition suppressed the self-renewing and tumor-initiating ability of dormant CSCs (95), suggesting that combining a marker-targeted treatment with a chemo- or radiation therapy may improve the treatment of liver cancer.

Some promising targets against LCSCs for the treatment of HCC can be found among the several signaling pathways that are essential for the development and maintenance of LCSCs (143). Constitutive expression of Wnt/ $\beta$-catenin was detected in LCSCs, and downregulation of it suppressed the cell phenotype (108). Employing different inhibitors of this pathway clearly impaired the viability of LCSCs as well as decreased the tumorigenicity in vitro and in vivo (151-153). Moreover, some phytochemicals have also been demonstrated to restrain the self-renewal and proliferationof LCSCs by suppressing Wnt/ $\beta$-catenin signaling (154, 155). Lupeol, another phytochemical, inhibited chemoresistance, selfrenewal ability, and tumorigenicity of $\mathrm{CD} 133^{+} \mathrm{CSCs}$, concomitantly sensitizing these cells to chemotherapeutic drugs via the PTEN-Akt-ABCG2 signaling pathway (156). Usage of a small molecule inhibitor targeting TGF- $\beta / S$ mad signaling followed by conventional therapy induced CSC differentiation, resulting in significant chemosensitization in vitro and in vivo (92).

Another interesting therapeutic approach is the induction of CSC differentiation into non-CSCs to lose their self-renewal property (149). Oncostatin M (OSM), an IL-6-related cytokine, is known to enhance differentiation of hepatoblasts into hepatocytes by inducing the activation of the STAT3 pathway (157). OSM effectively induced the differentiation of EpCAM ${ }^{+}$LCSCs. Moreover, 
combining oncostatin M treatment and 5-FU-based chemotherapy efficiently targeted both CSCs and non-CSCs and ultimately eliminated HCC (158). HNF4a is a key transcription factor for hepatocyte differentiation. Differentiation of hepatoma cells, especially CSCs, into hepatocytes could be induced by forced re-expression of this protein, which was associated with a decrease in stemness gene expression and the relative abundance of $\mathrm{CD} 33^{+}$and $\mathrm{CD} 90^{+}$cells (159). Arsenic trioxide also induced cell differentiation, consequently sensitizing LCSCs to conventional chemotherapy in HCC (160). All-trans retinoic acid effectively induced differentiation of TICs, which potentiated the cytotoxic effects of cisplatin (161). High-dose exogenous BMP4 promoted CD133+ LCSC differentiation and inhibited the self-renewal, chemotherapeutic resistance, and tumorigenic capacity of these cells (162). In addition, inducing differentiation of already premalignant hepatic cells via blocking of mCXCLl was proposed as a novel therapeutic strategy in HCC (163).

One of the recent approaches to target CSCs directly involves immunotherapies. Chimeric antigen receptor T cell (CAR-T) targeted against glypican-3 (an attractive liver cancer-specific target as it is highly expressed in HCC but displays limited expression in normal tissues) was shown to suppress HCC growth (164). CSC antigen-targeted CAR-T cells are therefore promising tools for the direct eradication of these cells.

Although numerous strategies for targeting LCSCs have been investigated, treatments for the eradication of CSCs still require further development until they are suitable to enter the clinics. Potential adverse effects on normal stem cells should be carefully evaluated because CSCs share similar features with normal stem cells. Therefore, the future challenge is to identify specific CSC markers and develop a specific treatment for LCSCs.

\section{CONCLUSION}

To improve diagnosis, prognosis, and treatment of HCC, it is of uttermost importance to get a much broader and deeper knowledge about the cancer-initiating cell as well as the cancer-propagating cell. For human cancer, the target cell population of malignant transformation is controversially discussed, but increasing evidence suggests that different cells of origin (Figure 1) as well as diverse genetic mutations account for cancer heterogeneity (58). More recent state-of-the art lineage tracing studies employing different models of experimental hepatocarcinogenesis highlight the role of hepatocytes as the cellular origin of HCC (Table 1). Not only these studies proved that tumors originated almost exclusively from hepatocytes but also ruled out a direct involvement of HPCs in initiating carcinogenesis. Nevertheless, most of the investigations were performed in animal models which have some limitations. Considering the fact that during chronic liver injury a variety of cells can respond to the need for cell replacement and liver regeneration (165-167), it is highly likely that the cell of origin of HCC is equally context-specific. Therefore, it is crucial to further strengthen the examination of human HCC, to identify the cells that give rise to liver tumors and elucidate the different classes of tumors based on their molecular features. 
Liver cancers with stemness traits are generally associated with a poor prognosis for patients, indicating that CSC markers have both diagnostic and prognostic potential. LCSCs are typically resistant to chemo- or radiotherapy as well as sorafenib treatment (Table 2) and have been shown to play critical roles in tumor progression, maintenance, and recurrence. Targeting surface markers or signaling pathways (Figure 1) in, or inducing differentiation of, these cells has already been demonstrated to interfere with tumorigenicity in preclinical studies. Although these data are promising, there are still some obstacles to overcome before similar strategies can enter the clinics. Specificity is one major concern since CSCs share identical features with normal stem cells that can be only resolved by unequivocally characterizing LCSCs. So far, the lack of a uniform definition of the CSC (sub) populations complicates the reliable comparison of results obtained using different approaches to isolate and characterize these cells. Furthermore, LCSCs are likely to be distinct and different for each individual tumor, according to genetic traits and activated signaling pathways. To define therapeutic targets specifically aimed at LCSCs, it is essential to face this challenge and consistently work on the elucidation of traits that confer CSC properties.

To conclude, the cellular mechanisms responsible for liver cancer initiation and progression need to be clearly defined to facilitate the detection of reliable tumor markers for diagnostic and prognostic applications and the development of new targeted therapy approaches for liver cancer.

Acknowledgements: Work of the authors was supported by the German Research Foundation (DFG): SFB TR209-Liver cancer: New mechanistic and therapeutic concepts in a solid tumor model.

Conflict of Interest: The authors declare no potential conflicts of interest with respect to research, authorship, and/or publication of this article.

Copyright and Permission: To the best of our knowledge, the materials included in this chapter do not violate copyright laws. All original sources have been appropriately acknowledged and/or referenced. Where relevant, appropriate permissions have been obtained from the original copyright holder(s).

\section{REFERENCES}

1. Llovet JM, Zucman-Rossi J, Pikarsky E, Sangro B, Schwartz M, Sherman M, et al. Hepatocellular carcinoma. Nat Rev Dis Primers. 2016;2:16018. http://dx.doi.org/10.1038/nrdp.2016.18

2. Forner A, Reig M, Bruix J. Hepatocellular carcinoma. Lancet. 2018;391:1301-14. http://dx.doi. org/10.1016/S0140-6736(18)30010-2

3. Gomaa AI, Waked I. Recent advances in multidisciplinary management of hepatocellular carcinoma. World J Hepatol. 2015;7:673-87. http://dx.doi.org/10.4254/wjh.v7.i4.673

4. Attwa MH, El-Etreby SA. Guide for diagnosis and treatment of hepatocellular carcinoma. World J Hepatol. 2015;7:1632-51. http://dx.doi.org/10.4254/wjh.v7.i12.1632

5. Niu L, Liu L, Yang S, Ren J, Lai PBS, Chen GG. New insights into sorafenib resistance in hepatocellular carcinoma: Responsible mechanisms and promising strategies. Biochim Biophys Acta Rev Cancer. 2017;1868:564-70. http://dx.doi.org/10.1016/j.bbcan.2017.10.002 
6. Horwitz E, Stein I, Andreozzi M, Nemeth J, Shoham A, Pappo O, et al. Human and mouse VEGFAamplified hepatocellular carcinomas are highly sensitive to sorafenib treatment. Cancer Discov. 2014;4:730-43. http://dx.doi.org/10.1158/2159-8290.CD-13-0782

7. Rudalska R, Dauch D, Longerich T, McJunkin K, Wuestefeld T, Kang TW, et al. In vivo RNAi screening identifies a mechanism of sorafenib resistance in liver cancer. Nat Med. 2014;20:1138-46. http:// dx.doi.org/10.1038/nm.3679

8. Zucman-Rossi J, Villanueva A, Nault JC, Llovet JM. Genetic landscape and biomarkers of hepatocellular carcinoma. Gastroenterology. 2015;149:1226-39 e1224. http://dx.doi.org/10.1053/j. gastro.2015.05.061

9. Dow M, Pyke RM, Tsui BY, Alexandrov LB, Nakagawa H, Taniguchi K, et al. Integrative genomic analysis of mouse and human hepatocellular carcinoma. Proc Natl Acad Sci U S A. 2018;115:E9879-88. http://dx.doi.org/10.1073/pnas.1811029115

10. Dauch D, Rudalska R, Cossa G, Nault JC, Kang TW, Wuestefeld T, et al. A MYC-aurora kinase A protein complex represents an actionable drug target in p53-altered liver cancer. Nat Med. 2016;22: 744-53. http://dx.doi.org/10.1038/nm.4107

11. Matter MS, Marquardt JU, Andersen JB, Quintavalle C, Korokhov N, Stauffer JK, et al. Oncogenic driver genes and the inflammatory microenvironment dictate liver tumor phenotype. Hepatology. 2016;63:1888-99. http://dx.doi.org/10.1002/hep.28487

12. Kondylis V, Polykratis A, Ehlken H, Ochoa-Callejero L, Straub BK, Krishna-Subramanian S, et al. NEMO prevents steatohepatitis and hepatocellular carcinoma by inhibiting RIPKl kinase activity-mediated hepatocyte apoptosis. Cancer Cell. 2015;28:582-98. http://dx.doi.org/10.1016/j.ccell.2015.10.001

13. Ringelhan M, Pfister D, O'Connor T, Pikarsky E, Heikenwalder M. The immunology of hepatocellular carcinoma. Nat Immunol. 2018;19:222-232. http://dx.doi.org/10.1038/s41590-018-0044-z

14. Schneider AT, Gautheron J, Feoktistova M, Roderburg C, Loosen SH, Roy S, et al. RIPKl suppresses a TRAF2-dependent pathway to liver cancer. Cancer Cell. 2017;31:94-109. http://dx.doi. org/10.1016/j.ccell.2016.11.009

15. Shalapour S, Lin XJ, Bastian IN, Brain J, Burt AD, Aksenov AA, et al. Inflammation-induced IgA+ cells dismantle anti-liver cancer immunity. Nature. 2017;551:340-5. http://dx.doi.org/10.1038/nature24302

16. Eggert T, Wolter K, Ji J, Ma C, Yevsa T, Klotz S, et al. Distinct functions of senescence-associated immune responses in liver tumor surveillance and tumor progression. Cancer Cell. 2016;30:533-47. http://dx.doi.org/10.1016/j.ccell.2016.09.003

17. Endig J, Buitrago-Molina LE, Marhenke S, Reisinger F, Saborowski A, Schutt J, et al. Dual role of the adaptive immune system in liver injury and hepatocellular carcinoma development. Cancer Cell. 2016;30:308-23. http://dx.doi.org/10.1016/j.ccell.2016.06.009

18. Ma C, Kesarwala AH, Eggert T, Medina-Echeverz J, Kleiner DE, Jin P, et al. NAFLD causes selective CD4(+) T lymphocyte loss and promotes hepatocarcinogenesis. Nature. 2016;531:253-7. http:// dx.doi.org/10.1038/nature16969

19. Seehawer M, Heinzmann F, D'Artista L, Harbig J, Roux PF, Hoenicke L, et al. Necroptosis microenvironment directs lineage commitment in liver cancer. Nature. 2018;562:69-75. http://dx.doi. org/10.1038/s41586-018-0519-y

20. Pusterla T, Nemeth J, Stein I, Wiechert L, Knigin D, Marhenke S, et al. Receptor for advanced glycation endproducts (RAGE) is a key regulator of oval cell activation and inflammation-associated liver carcinogenesis in mice. Hepatology. 2013;58:363-73. http://dx.doi.org/10.1002/hep.26395

21. Calderaro J, Couchy G, Imbeaud S, Amaddeo G, Letouze E, Blanc JF, et al. Histological subtypes of hepatocellular carcinoma are related to gene mutations and molecular tumour classification. J Hepatol. 2017;67:727-38. http://dx.doi.org/10.1016/j.jhep.2017.05.014

22. Nault JC, Zucman-Rossi J. Genetics of hepatobiliary carcinogenesis. Semin Liver Dis. 2011;31:173-87. http://dx.doi.org/10.1055/s-0031-1276646

23. Lee JS, Heo J, Libbrecht L, Chu IS, Kaposi-Novak P, Calvisi DF, et al. A novel prognostic subtype of human hepatocellular carcinoma derived from hepatic progenitor cells. Nat Med. 2006;12:410-16. http://dx.doi.org/10.1038/nm1377

24. Yamashita T, Forgues M, Wang W, Kim JW, Ye Q, Jia H, et al. EpCAM and alpha-fetoprotein expression defines novel prognostic subtypes of hepatocellular carcinoma. Cancer Res. 2008;68:1451-61. http:// dx.doi.org/10.1158/0008-5472.CAN-07-6013 
25. Holczbauer A, Factor VM, Andersen JB, Marquardt JU, Kleiner DE, Raggi C, et al. Modeling pathogenesis of primary liver cancer in lineage-specific mouse cell types. Gastroenterology. 2013;145:221-31. http://dx.doi.org/10.1053/j.gastro.2013.03.013

26. Katz SF, Lechel A, Obenauf AC, Begus-Nahrmann Y, Kraus JM, Hoffmann EM, et al. Disruption of Trp53 in livers of mice induces formation of carcinomas with bilineal differentiation. Gastroenterology. 2012;142:1229-39 e1223. http://dx.doi.org/10.1053/j.gastro.2012.02.009

27. Bakiri L, Wagner EF. Mouse models for liver cancer. Mol Oncol. 2013;7:206-23. http://dx.doi. org/10.1016/j.molonc.2013.01.005

28. Brown ZJ, Heinrich B, Greten TF. Mouse models of hepatocellular carcinoma: An overview and highlights for immunotherapy research. Nat Rev Gastroenterol Hepatol. 2018;15:536-54. http://dx.doi. org/10.1038/s41575-018-0033-6

29. Caviglia JM, Schwabe RF. Mouse models of liver cancer. Methods Mol Biol. 2015;1267:165-83. http:// dx.doi.org/10.1007/978-1-4939-2297-0_8

30. He L, Tian DA, Li PY, He XX. Mouse models of liver cancer: Progress and recommendations. Oncotarget. 2015;6:23306-22. http://dx.doi.org/10.18632/oncotarget.4202

31. Zender L, Spector MS, Xue W, Flemming P, Cordon-Cardo C, Silke J, et al. Identification and validation of oncogenes in liver cancer using an integrative oncogenomic approach. Cell. 2006;125: 1253-67. http://dx.doi.org/10.1016/j.cell.2006.05.030

32. Tang Y, Kitisin K, Jogunoori W, Li C, Deng CX, Mueller SC, et al. Progenitor/stem cells give rise to liver cancer due to aberrant TGF-beta and IL-6 signaling. Proc Natl Acad Sci U S A. 2008;105:2445-50. http://dx.doi.org/10.1073/pnas.0705395105

33. Wu K, Ding J, Chen C, Sun W, Ning BF, Wen W, et al. Hepatic transforming growth factor beta gives rise to tumor-initiating cells and promotes liver cancer development. Hepatology. 2012;56:2255-67. http://dx.doi.org/10.1002/hep.26007

34. Lu L, Li Y, Kim SM, Bossuyt W, Liu P, Qiu Q, et al. Hippo signaling is a potent in vivo growth and tumor suppressor pathway in the mammalian liver. Proc Natl Acad Sci U S A. 2010;107:1437-42. http://dx.doi.org/10.1073/pnas.0911427107

35. Xu MZ, Yao TJ, Lee NP, Ng IO, Chan YT, Zender L, et al. Yes-associated protein is an independent prognostic marker in hepatocellular carcinoma. Cancer. 2009;115:4576-85. http://dx.doi. org/10.1002/cncr.24495

36. Weiler SME, Pinna F, Wolf T, Lutz T, Geldiyev A, Sticht C, et al. Induction of Chromosome Instability by activation of yes-associated protein and forkhead box Ml in liver cancer. Gastroenterology. 2017;152:2037-51 e2022. http://dx.doi.org/10.1053/j.gastro.2017.02.018

37. Benhamouche S, Curto M, Saotome I, Gladden AB, Liu CH, Giovannini M, et al. Nf2/Merlin controls progenitor homeostasis and tumorigenesis in the liver. Genes Dev 2010;24:1718-30. http://dx.doi. org/10.1101/gad.1938710

38. Villanueva A, Alsinet C, Yanger K, Hoshida Y, Zong Y, Toffanin S, et al. Notch signaling is activated in human hepatocellular carcinoma and induces tumor formation in mice. Gastroenterology. 2012;143:1660-69 e1667. http://dx.doi.org/10.1053/j.gastro.2012.09.002

39. Furuyama K, Kawaguchi Y, Akiyama H, Horiguchi M, Kodama S, Kuhara T, et al. Continuous cell supply from a Sox9-expressing progenitor zone in adult liver, exocrine pancreas and intestine. Nat Genet. 2011;43:34-41. http://dx.doi.org/10.1038/ng.722

40. Mokkapati S, Niopek K, Huang L, Cunniff KJ, Ruteshouser EC, deCaestecker M, et al. beta-catenin activation in a novel liver progenitor cell type is sufficient to cause hepatocellular carcinoma and hepatoblastoma. Cancer Res. 2014;74:4515-25. http://dx.doi.org/10.1158/0008-5472.CAN-13-3275

41. Harada N, Oshima H, Katoh M, Tamai Y, Oshima M, Taketo MM. Hepatocarcinogenesis in mice with beta-catenin and Ha-ras gene mutations. Cancer Res. 2004;64:48-54. http://dx.doi.org/10.1158/00085472.CAN-03-2123

42. Stauffer JK, Scarzello AJ, Andersen JB, De Kluyver RL, Back TC, Weiss JM, et al. Coactivation of AKT and beta-catenin in mice rapidly induces formation of lipogenic liver tumors. Cancer Res. 2011;71:2718-2727. http://dx.doi.org/10.1158/0008-5472.CAN-10-2705

43. Nikolaou KC, Moulos P, Chalepakis G, Hatzis P, Oda H, Reinberg D, et al. Spontaneous development of hepatocellular carcinoma with cancer stem cell properties in PR-SET7-deficient livers. EMBO J. 2015;34:430-47. http://dx.doi.org/10.15252/embj.201489279 
44. Andersen JB, Loi R, Perra A, Factor VM, Ledda-Columbano GM, Columbano A, et al. Progenitorderived hepatocellular carcinoma model in the rat. Hepatology. 2010;51:1401-9. http://dx.doi. org/10.1002/hep.23488

45. Zheng YW, Tsuchida T, Shimao T, Li B, Takebe T, Zhang RR, et al. The CD133+CD44+ precancerous subpopulation of oval cells is a therapeutic target for hepatocellular carcinoma. Stem Cells Dev. 2014;23:2237-49. http://dx.doi.org/10.1089/scd.2013.0577

46. Matsumoto T, Takai A, Eso Y, Kinoshita K, Manabe T, Seno H, et al. Proliferating EpCAM-positive ductal cells in the inflamed liver give rise to hepatocellular carcinoma. Cancer Res. 2017;77:6131-43. http://dx.doi.org/10.1158/0008-5472.CAN-17-1800

47. Sia D, Villanueva A, Friedman SL, Llovet JM. Liver cancer cell of origin, molecular class, and effects on patient prognosis. Gastroenterology. 2017;152:745-61. http://dx.doi.org/10.1053/j. gastro.2016.11.048

48. Umemura A, He F, Taniguchi K, Nakagawa H, Yamachika S, Font-Burgada J, et al. p62, upregulated during preneoplasia, induces hepatocellular carcinogenesis by maintaining survival of stressed HCCinitiating cells. Cancer Cell. 2016;29:935-48. http://dx.doi.org/10.1016/j.ccell.2016.04.006

49. Zhou M, Yang H, Learned RM, Tian H, Ling L. Non-cell-autonomous activation of IL-6/STAT3 signaling mediates FGF19-driven hepatocarcinogenesis. Nat Commun. 2017;8:15433. http://dx.doi. org/10.1016/j.ccell.2016.04.006

50. Jors S, Jeliazkova P, Ringelhan M, Thalhammer J, Durl S, Ferrer J, et al. Lineage fate of ductular reactions in liver injury and carcinogenesis. J Clin Invest. 2015;125:2445-57. http://dx.doi.org/10.1172/ JCI78585

51. Mu X, Espanol-Suner R, Mederacke I, Affo S, Manco R, Sempoux C, et al. Hepatocellular carcinoma originates from hepatocytes and not from the progenitor/biliary compartment. J Clin Invest. 2015;125:3891-903. http://dx.doi.org/10.1172/JCI77995

52. Tschaharganeh DF, Xue W, Calvisi DF, Evert M, Michurina TV, Dow LE, et al. p53-dependent nestin regulation links tumor suppression to cellular plasticity in liver cancer. Cell 2016;165:1546-47. http://dx.doi.org/10.1016/j.cell.2016.05.058

53. Shin S, Wangensteen KJ, Teta-Bissett M, Wang YJ, Mosleh-Shirazi E, Buza EL, et al. Genetic lineage tracing analysis of the cell of origin of hepatotoxin-induced liver tumors in mice. Hepatology. 2016;64:1163-77. http://dx.doi.org/10.1002/hep.28602

54. Tummala KS, Brandt M, Teijeiro A, Grana O, Schwabe RF, Perna C, et al. Hepatocellular carcinomas originate predominantly from hepatocytes and benign lesions from hepatic progenitor cells. Cell Rep. 2017;19:584-600. http://dx.doi.org/10.1016/j.celrep.2017.03.059

55. Itoh T. Stem/progenitor cells in liver regeneration. Hepatology. 2016;64:663-68. http://dx.doi. org/10.1002/hep.28661

56. Clevers H. The cancer stem cell: Premises, promises and challenges. Nat Med. 2011;17:313-19. http://dx.doi.org/10.1038/nm.2304

57. Wicha MS, Liu S, Dontu G. Cancer stem cells: an old idea--a paradigm shift. Cancer Res. 2006; 66:1883-90; discussion 1895-1886. http://dx.doi.org/10.1158/0008-5472.CAN-05-3153

58. Yamashita T, Wang XW. Cancer stem cells in the development of liver cancer. J Clin Invest. 2013;123:1911-18. http://dx.doi.org/10.1172/JCI66024

59. Chiba T, Kita K, Zheng YW, Yokosuka O, Saisho H, Iwama A, et al. Side population purified from hepatocellular carcinoma cells harbors cancer stem cell-like properties. Hepatology. 2006;44:240-51. http://dx.doi.org/10.1002/hep.21227

60. Xia H, Cao J, Li Q, Lv Y, Jia W, Ren W, et al. Hepatocellular carcinoma-propagating cells are detectable by side population analysis and possess an expression profile reflective of a primitive origin. Sci Rep. 2016;6:34856. http://dx.doi.org/10.1038/srep34856

61. He G, Dhar D, Nakagawa H, Font-Burgada J, Ogata H, Jiang Y, et al. Identification of liver cancer progenitors whose malignant progression depends on autocrine IL-6 signaling. Cell. 2013;155:384-96. http://dx.doi.org/10.1016/j.cell.2013.09.031

62. Finkin S, Yuan D, Stein I, Taniguchi K, Weber A, Unger K, et al. Ectopic lymphoid structures function as microniches for tumor progenitor cells in hepatocellular carcinoma. Nat Immunol. 2015;16: 1235-44. http://dx.doi.org/10.1038/ni.3290 
63. Rountree CB, Barsky L, Ge S, Zhu J, Senadheera S, Crooks GM. A CDl33-expressing murine liver oval cell population with bilineage potential. Stem Cells. 2007;25:2419-29. http://dx.doi.org/10.1634/ stemcells.2007-0176

64. Song W, Li H, Tao K, Li R, Song Z, Zhao Q, et al. Expression and clinical significance of the stem cell marker CD133 in hepatocellular carcinoma. Int J Clin Pract. 2008;62:1212-18. http://dx.doi. org/10.1111/j.1742-1241.2008.01777.x

65. Ma YC, Yang JY, Yan LN. Relevant markers of cancer stem cells indicate a poor prognosis in hepatocellular carcinoma patients: A meta-analysis. Eur J Gastroenterol Hepatol. 2013;25:1007-16. http:// dx.doi.org/10.1097/MEG.0b013e32836019d8

66. Suetsugu A, Nagaki M, Aoki H, Motohashi T, Kunisada T, Moriwaki H. Characterization of CD133+ hepatocellular carcinoma cells as cancer stem/progenitor cells. Biochem Biophys Res Commun. 2006;351:820-4. http://dx.doi.org/10.1016/j.bbrc.2006.10.128

67. Yin S, Li J, Hu C, Chen X, Yao M, Yan M, et al. CD133 positive hepatocellular carcinoma cells possess high capacity for tumorigenicity. Int J Cancer. 2007;120:1444-50. http://dx.doi.org/10.1002/ ijc. 22476

68. Ma S, Chan KW, Hu L, Lee TK, Wo JY, Ng IO, et al. Identification and characterization of tumorigenic liver cancer stem/progenitor cells. Gastroenterology. 2007;132:2542-56. http://dx.doi.org/10.1053/j. gastro.2007.04.025

69. Ma S, Tang KH, Chan YP, Lee TK, Kwan PS, Castilho A, et al. miR-130b Promotes CD133(+) liver tumor-initiating cell growth and self-renewal via tumor protein 53-induced nuclear protein 1 . Cell Stem Cell. 2010;7:694-707. http://dx.doi.org/10.1016/j.stem.2010.11.010

70. Tang KH, Ma S, Lee TK, Chan YP, Kwan PS, Tong CM, et al. CD133(+) liver tumor-initiating cells promote tumor angiogenesis, growth, and self-renewal through neurotensin/interleukin-8/CXCL1 signaling. Hepatology. 2012;55:807-20. http://dx.doi.org/10.1002/hep.24739

71. Dhar D, Antonucci L, Nakagawa H, Kim JY, Glitzner E, Caruso S, et al. Liver cancer initiation requires p53 inhibition by CD44-enhanced growth factor signaling. Cancer Cell. 2018;33:1061-77 el066. http://dx.doi.org/10.1016/j.ccell.2018.05.003

72. Mima K, Okabe H, Ishimoto T, Hayashi H, Nakagawa S, Kuroki H, et al. CD44s regulates the TGFbeta-mediated mesenchymal phenotype and is associated with poor prognosis in patients with hepatocellular carcinoma. Cancer Res. 2012;72:3414-23. http://dx.doi.org/10.1158/0008-5472. CAN-12-0299

73. Asai R, Tsuchiya H, Amisaki M, Makimoto K, Takenaga A, Sakabe T, et al. CD44 standard isoform is involved in maintenance of cancer stem cells of a hepatocellular carcinoma cell line. Cancer Med. 2019;8:773-82. http://dx.doi.org/10.1002/cam4.1968

74. Wan S, Zhao E, Kryczek I, Vatan L, Sadovskaya A, Ludema G, et al. Tumor-associated macrophages produce interleukin 6 and signal via STAT3 to promote expansion of human hepatocellular carcinoma stem cells. Gastroenterology. 2014;147:1393-1404. http://dx.doi.org/10.1053/j.gastro.2014.08.039

75. Zhu Z, Hao X, Yan M, Yao M, Ge C, Gu J, et al. Cancer stem/progenitor cells are highly enriched in CD133+CD44+ population in hepatocellular carcinoma. Int J Cancer. 2010;126:2067-78. http:// dx.doi.org/10.1002/ijc. 24868

76. Hou Y, Zou Q, Ge R, Shen F, Wang Y. The critical role of CD133(+)CD44(+/high) tumor cells in hematogenous metastasis of liver cancers. Cell Res. 2012;22:259-72. http://dx.doi.org/10.1038/ cr.2011.139

77. Vilchez V, Turcios L, Zaytseva Y, Stewart R, Lee EY, Maynard E, et al. Cancer stem cell marker expression alone and in combination with microvascular invasion predicts poor prognosis in patients undergoing transplantation for hepatocellular carcinoma. Am J Surg. 2016;212:238-45. http://dx.doi.org/10.1016/j.amjsurg.2015.12.019

78. Lu S, Yao Y, Xu G, Zhou C, Zhang Y, Sun J, et al. CD24 regulates sorafenib resistance via activating autophagy in hepatocellular carcinoma. Cell Death Dis. 2018;9:646. http://dx.doi.org/10.1038/ s41419-018-0681-z

79. Lee TK, Castilho A, Cheung VC, Tang KH, Ma S, Ng IO. CD24(+) liver tumor-initiating cells drive self-renewal and tumor initiation through STAT3-mediated NANOG regulation. Cell Stem Cell. 2011;9:50-63. http://dx.doi.org/10.1016/j.stem.2011.06.005 
80. Liu AY, Cai Y, Mao Y, Lin Y, Zheng H, Wu T, et al. Twist2 promotes self-renewal of liver cancer stem-like cells by regulating CD24. Carcinogenesis. 2014;35:537-45. http://dx.doi.org/10.1093/carcin/bgt364

81. Li Y, Wang R, Xiong S, Wang X, Zhao Z, Bai S, et al. Cancer-associated fibroblasts promote the stemness of CD24(+) liver cells via paracrine signaling. J Mol Med (Berl). 2019;97:243-55. http://dx.doi. org/10.1007/s00109-018-1731-9

82. Wang R, Li Y, Tsung A, Huang H, Du Q, Yang M, et al. iNOS promotes CD24(+)CD133(+) liver cancer stem cell phenotype through a TACE/ADAM17-dependent Notch signaling pathway. Proc Natl Acad Sci U S A. 2018;115:E10127-36. http://dx.doi.org/10.1073/pnas.1722100115

83. Imrich S, Hachmeister M, Gires O. EpCAM and its potential role in tumor-initiating cells. Cell Adh Migr. 2012;6:30-8. http://dx.doi.org/10.4161/cam.18953

84. Yamashita T, Budhu A, Forgues M, Wang XW. Activation of hepatic stem cell marker EpCAM by Wntbeta-catenin signaling in hepatocellular carcinoma. Cancer Res. 2007;67:10831-9. http://dx.doi. org/10.1158/0008-5472.CAN-07-0908

85. Wang C, Fu SY, Wang MD, Yu WB, Cui QS, Wang HR, et al. Zinc finger protein X-linked promotes expansion of EpCAM(+) cancer stem-like cells in hepatocellular carcinoma. Mol Oncol. 2017;11: 455-69. http://dx.doi.org/10.1002/1878-0261.12036

86. Yamashita T, Ji J, Budhu A, Forgues M, Yang W, Wang HY, et al. EpCAM-positive hepatocellular carcinoma cells are tumor-initiating cells with stem/progenitor cell features. Gastroenterology. 2009;136:1012-24. http://dx.doi.org/10.1053/j.gastro.2008.12.004

87. Terris B, Cavard C, Perret C. EpCAM, a new marker for cancer stem cells in hepatocellular carcinoma. J Hepatol. 2010;52:280-1. http://dx.doi.org/10.1016/j.jhep.2009.10.026

88. Chen Y, Yu D, Zhang H, He H, Zhang C, Zhao W, et al. CD133(+)EpCAM(+) phenotype possesses more characteristics of tumor initiating cells in hepatocellular carcinoma Huh7 cells. Int J Biol Sci. 2012;8:992-1004. http://dx.doi.org/10.7150/ijbs.4454

89. Yang ZF, Ngai P, Ho DW, Yu WC, Ng MN, Lau CK, et al. Identification of local and circulating cancer stem cells in human liver cancer. Hepatology. 2008;47:919-28. http://dx.doi.org/10.1002/hep.22082

90. Yang ZF, Ho DW, Ng MN, Lau CK, Yu WC, Ngai P, et al. Significance of CD90+ cancer stem cells in human liver cancer. Cancer Cell. 2008;13:153-66. http://dx.doi.org/10.1016/j.ccr.2008.01.013

91. Yamashita T, Honda M, Nakamoto Y, Baba M, Nio K, Hara Y, et al. Discrete nature of EpCAM+ and CD90+ cancer stem cells in human hepatocellular carcinoma. Hepatology. 2013;57:1484-97. http:// dx.doi.org/10.1002/hep.26168

92. Xia W, Lo CM, Poon RYC, Cheung TT, Chan ACY, Chen L, et al. Smad inhibitor induces CSC differentiation for effective chemosensitization in cyclin Dl- and TGF-beta/Smad-regulated liver cancer stem cell-like cells. Oncotarget. 2017;8:38811-24. http://dx.doi.org/10.18632/oncotarget.16402

93. Ho DW, Yang ZF, Yi K, Lam CT, Ng MN, Yu WC, et al. Gene expression profiling of liver cancer stem cells by RNA-sequencing. PLoS One. 2012;7:e37159. http://dx.doi.org/10.1371/journal. pone.0037159

94. Yamanaka C, Wada H, Eguchi H, Hatano H, Gotoh K, Noda T, et al. Clinical significance of CD13 and epithelial mesenchymal transition (EMT) markers in hepatocellular carcinoma. Jpn J Clin Oncol. 2018;48:52-60. http://dx.doi.org/10.1093/jjco/hyx157

95. Haraguchi N, Ishii H, Mimori K, Tanaka F, Ohkuma M, Kim HM, et al. CD13 is a therapeutic target in human liver cancer stem cells. J Clin Invest. 2010;120:3326-39. http://dx.doi.org/10.1172/JCI42550

96. Christ B, Stock P, Dollinger MM. CD13: Waving the flag for a novel cancer stem cell target. Hepatology. 2011;53:1388-90. http://dx.doi.org/10.1002/hep.24222

97. Nagano H, Ishii H, Marubashi S, Haraguchi N, Eguchi H, Doki Y, et al. Novel therapeutic target for cancer stem cells in hepatocellular carcinoma. J Hepatobiliary Pancreat Sci. 2012;19:600-5. http:// dx.doi.org/10.1007/s00534-012-0543-5

98. Kim HM, Haraguchi N, Ishii H, Ohkuma M, Okano M, Mimori K, et al. Increased CD13 expression reduces reactive oxygen species, promoting survival of liver cancer stem cells via an epithelial-mesenchymal transition-like phenomenon. Ann Surg Oncol. 2012;19(Suppl 3):S539-48. http://dx.doi. org/10.1007/s00534-012-0543-5

99. Crosby HA, Hubscher SG, Joplin RE, Kelly DA, Strain AJ. Immunolocalization of OV-6, a putative progenitor cell marker in human fetal and diseased pediatric liver. Hepatology. 1998;28:980-5. http:// dx.doi.org/10.1002/hep.510280412 
100. Yang W, Yan HX, Chen L, Liu Q, He YQ, Yu LX, et al. Wnt/beta-catenin signaling contributes to activation of normal and tumorigenic liver progenitor cells. Cancer Res. 2008;68:4287-95. http://dx.doi. org/10.1158/0008-5472.CAN-07-6691

101. Zhang A, London R, Schulz FM, Giguere-Simmonds PW, Delriviere L, Chandraratana H, et al. Human liver progenitor cell lines are readily established from non-tumorous tissue adjacent to hepatocellular carcinoma. Stem Cells Dev. 2010;19:1277-84. http://dx.doi.org/10.1089/scd.2009.0304

102. Yang W, Wang C, Lin Y, Liu Q, Yu LX, Tang L, et al. OV6(+) tumor-initiating cells contribute to tumor progression and invasion in human hepatocellular carcinoma. J Hepatol. 2012;57:613-20. http:// dx.doi.org/10.1016/j.jhep.2012.04.024

103. Liu LL, Fu D, Ma Y, Shen XZ. The power and the promise of liver cancer stem cell markers. Stem Cells Dev. 2011;20:2023-30. http://dx.doi.org/10.1089/scd.2011.0012

104. Wilson GS, Hu Z, Duan W, Tian A, Wang XM, McLeod D, et al. Efficacy of using cancer stem cell markers in isolating and characterizing liver cancer stem cells. Stem Cells Dev. 2013;22:2655-64. http://dx.doi.org/10.1089/scd.2011.0012

105. Wang R, Sun Q, Wang P, Liu M, Xiong S, Luo J, et al. Notch and Wnt/beta-catenin signaling pathway play important roles in activating liver cancer stem cells. Oncotarget. 2016;7:5754-68. http://dx.doi. org/10.18632/oncotarget.6805

106. Flores-Tellez TN, Villa-Trevino S, Pina-Vazquez C. Road to stemness in hepatocellular carcinoma. World J Gastroenterol. 2017;23:6750-76. http://dx.doi.org/10.3748/wjg.v23.i37.6750

107. Totoki Y, Tatsuno K, Covington KR, Ueda H, Creighton CJ, Kato M, et al. Trans-ancestry mutational landscape of hepatocellular carcinoma genomes. Nat Genet. 2014;46:1267-73. http://dx.doi. org/10.1038/ng.3126

108. Chen W, Zhang YW, Li Y, Zhang JW, Zhang T, Fu BS, et al. Constitutive expression of Wnt/ betacatenin target genes promotes proliferation and invasion of liver cancer stem cells. Mol Med Rep. 2016;13:3466-74. http://dx.doi.org/10.3892/mmr.2016.4986

109. Wielenga VJ, Smits R, Korinek V, Smit L, Kielman M, Fodde R, et al. Expression of CD44 in Apc and Tcf mutant mice implies regulation by the WNT pathway. Am J Pathol. 1999;154:515-23. http:// dx.doi.org/10.1016/S0002-9440(10)65297-2

110. He TC, Sparks AB, Rago C, Hermeking H, Zawel L, da Costa LT, et al. Identification of c-MYC as a target of the APC pathway. Science. 1998;281:1509-12. http://dx.doi.org/10.1126/science. 281.5382.1509

111. Ranganathan P, Weaver KL, Capobianco AJ. Notch signalling in solid tumours: A little bit of everything but not all the time. Nat Rev Cancer. 2011;11:338-51. http://dx.doi.org/10.1038/nrc3035

112. Luo J, Wang P, Wang R, Wang J, Liu M, Xiong S, et al. The Notch pathway promotes the cancer stem cell characteristics of CD90+ cells in hepatocellular carcinoma. Oncotarget. 2016;7:9525-37. http:// dx.doi.org/10.18632/oncotarget.6672

113. Jeng KS, Sheen IS, Jeng WJ, Yu MC, Hsiau HI, Chang FY, et al. Activation of the sonic hedgehog signaling pathway occurs in the CD133 positive cells of mouse liver cancer Hepa 1-6 cells. Onco Targets Ther. 2013;6:1047-55. http://dx.doi.org/10.2147/OTT.S44828

114. Xie G, Karaca G, Swiderska-Syn M, Michelotti GA, Kruger L, Chen Y, et al. Cross-talk between Notch and Hedgehog regulates hepatic stellate cell fate in mice. Hepatology. 2013;58:1801-13. http:// dx.doi.org/10.1002/hep.26511

115. Dooley S, ten Dijke P. TGF-beta in progression of liver disease. Cell Tissue Res. 2012;347:245-56. http://dx.doi.org/10.1007/s00441-011-1246-y

116. Nishimura T, Azuma T, Yokoyama A, Ochiai H, Saito H, Hibi T. New mechanism of transforming growth factor-beta signaling in hepatoma: Dramatic up-regulation of tumor initiating cells and epidermal growth factor receptor expression. Hepatol Res. 2009;39:501-9. http://dx.doi. org/10.1111/j.1872-034X.2008.00480.x

117. Kim JB, Lee S, Kim HR, Park SY, Lee M, Yoon JH, et al. Transforming growth factor-beta decreases side population cells in hepatocellular carcinoma in vitro. Oncol Lett. 2018;15:8723-8. http://dx.doi. org/10.3892/ol.2018.8441

118. You H, Ding W, Rountree CB. Epigenetic regulation of cancer stem cell marker CD133 by transforming growth factor-beta. Hepatology. 2010;51:1635-44. http://dx.doi.org/10.1002/hep.23544 
119. Malfettone A, Soukupova J, Bertran E, Crosas-Molist E, Lastra R, Fernando J, et al. Transforming growth factor-beta-induced plasticity causes a migratory stemness phenotype in hepatocellular carcinoma. Cancer Lett. 2017;392:39-50. http://dx.doi.org/10.1016/j.canlet.2017.01.037

120. Jing L, Ruan Z, Sun H, Li Q, Han L, Huang L, et al. Epithelial-mesenchymal transition induced cancerstem-cell-like characteristics in hepatocellular carcinoma. J Cell Physiol. 2019;234(10):18448-58. http://dx.doi.org/10.1002/jcp.28480

121. Fan QM, Jing YY, Yu GF, Kou XR, Ye F, Gao L, et al. Tumor-associated macrophages promote cancer stem cell-like properties via transforming growth factor-betal-induced epithelial-mesenchymal transition in hepatocellular carcinoma. Cancer Lett. 2014;352:160-8. http://dx.doi.org/10.1016/j. canlet.2014.05.008

122. Yuan F, Zhou W, Zou C, Zhang Z, Hu H, Dai Z, et al. Expression of Oct4 in HCC and modulation to wnt/beta-catenin and TGF-beta signal pathways. Mol Cell Biochem. 2010;343:155-62. http://dx.doi. org/10.1007/s11010-010-0509-3

123. Marquardt JU, Raggi C, Andersen JB, Seo D, Avital I, Geller D, et al. Human hepatic cancer stem cells are characterized by common stemness traits and diverse oncogenic pathways. Hepatology. 2011;54:1031-42. http://dx.doi.org/10.1002/hep.24454

124. Tirino V, Desiderio V, Paino F, Papaccio G, De Rosa M. Methods for cancer stem cell detection and isolation. Methods Mol Biol. 2012;879:513-29. http://dx.doi.org/10.1002/hep.24454

125. Rycaj K, Tang DG. Cell-of-origin of cancer versus cancer stem cells: Assays and interpretations. Cancer Res. 2015;75:4003-11. http://dx.doi.org/10.1158/0008-5472.CAN-15-0798

126. Cao L, Zhou Y, Zhai B, Liao J, Xu W, Zhang R, et al. Sphere-forming cell subpopulations with cancer stem cell properties in human hepatoma cell lines. BMC Gastroenterol. 2011;11:71. http://dx.doi. org/10.1186/1471-230X-11-71

127. Jia Q, Zhang X, Deng T, Gao J. Positive correlation of Oct4 and ABCG2 to chemotherapeutic resistance in CD90(+)CD133(+) liver cancer stem cells. Cell Reprogram. 2013;15:143-50. http://dx.doi. org/10.1089/cell.2012.0048

128. Dean M, Fojo T, Bates S. Tumour stem cells and drug resistance. Nat Rev Cancer. 2005;5:275-84. http://dx.doi.org/10.1038/nrc1590

129. Franken NA, Rodermond HM, Stap J, Haveman J, van Bree C. Clonogenic assay of cells in vitro. Nat Protoc. 2006;1:2315-19. http://dx.doi.org/10.1038/nprot.2006.339

130. Hoffman RM. In vitro sensitivity assays in cancer: A review, analysis, and prognosis. J Clin Lab Anal. 1991;5:133-43. http://dx.doi.org/10.1002/jcla.1860050211

131. Pastrana E, Silva-Vargas V, Doetsch F. Eyes wide open: A critical review of sphere-formation as an assay for stem cells. Cell Stem Cell. 2011;8:486-98. http://dx.doi.org/10.1016/j.stem.2011.04.007

132. Mehta G, Hsiao AY, Ingram M, Luker GD, Takayama S. Opportunities and challenges for use of tumor spheroids as models to test drug delivery and efficacy. J Control Release. 2012;164:192-204. http:// dx.doi.org/10.1016/j.jconrel.2012.04.045

133. Dobbin ZC, Landen CN. Isolation and characterization of potential cancer stem cells from solid human tumors-Potential applications. Curr Protoc Pharmacol. 2013;63:Unit 14 28. http://dx.doi. org/10.1002/0471141755.ph1428s63

134. Kohn-Gaone J, Gogoi-Tiwari J, Ramm GA, Olynyk JK, Tirnitz-Parker JE. The role of liver progenitor cells during liver regeneration, fibrogenesis, and carcinogenesis. Am J Physiol Gastrointest Liver Physiol. 2016;310:G143-54. http://dx.doi.org/10.1152/ajpgi.00215.2015

135. Wang N, Wang S, Li MY, Hu BG, Liu LP, Yang SL, et al. Cancer stem cells in hepatocellular carcinoma: An overview and promising therapeutic strategies. Ther Adv Med Oncol. 2018;10:1758835918816287. http://dx.doi.org/10.1177/1758835918816287

136. Ma S, Lee TK, Zheng BJ, Chan KW, Guan XY. CD133+ HCC cancer stem cells confer chemoresistance by preferential expression of the Akt/PKB survival pathway. Oncogene. 2008;27:1749-58. http:// dx.doi.org/10.1038/sj.onc.1210811

137. Piao LS, Hur W, Kim TK, Hong SW, Kim SW, Choi JE, et al. CD133+ liver cancer stem cells modulate radioresistance in human hepatocellular carcinoma. Cancer Lett. 2012;315:129-37. http://dx.doi. org/10.1016/j.canlet.2011.10.012

138. Lan X, Wu YZ, Wang Y, Wu FR, Zang CB, Tang C, et al. CD133 silencing inhibits stemness properties and enhances chemoradiosensitivity in CD133-positive liver cancer stem cells. Int J Mol Med. 2013;31:315-24. http://dx.doi.org/10.3892/ijmm.2012.1208 
139. Kim BH, Park JW, Kim JS, Lee SK, Hong EK. Stem Cell Markers Predict the Response to Sorafenib in Patients with Hepatocellular Carcinoma. Gut Liver. 2018;13(3):342-48.

140. Chow AK, Ng L, Lam CS, Wong SK, Wan TM, Cheng NS, et al. The enhanced metastatic potential of hepatocellular carcinoma (HCC) cells with sorafenib resistance. PLoS One. 2013;8:e78675. http:// dx.doi.org/10.1371/journal.pone.0078675

141. Guan DX, Shi J, Zhang Y, Zhao JS, Long LY, Chen TW, et al. Sorafenib enriches epithelial cell adhesion molecule-positive tumor initiating cells and exacerbates a subtype of hepatocellular carcinoma through TSC2-AKT cascade. Hepatology. 2015;62:1791-803. http://dx.doi.org/10.1002/hep.28117

142. Xin HW, Ambe CM, Hari DM, Wiegand GW, Miller TC, Chen JQ, et al. Label-retaining liver cancer cells are relatively resistant to sorafenib. Gut. 2013;62:1777-86. http://dx.doi.org/10.1136/gutjnl-2012-303261

143. Li N, Zhu Y. Targeting liver cancer stem cells for the treatment of hepatocellular carcinoma. Therap Adv Gastroenterol. 2019;12:1756284818821560. http://dx.doi.org/10.1177/1756284818821560

144. Cairo S, Wang Y, de Reynies A, Duroure K, Dahan J, Redon MJ, et al. Stem cell-like micro-RNA signature driven by Myc in aggressive liver cancer. Proc Natl Acad Sci U S A. 2010;107:20471-6. http:// dx.doi.org/10.1073/pnas.1009009107

145. Woo HG, Wang XW, Budhu A, Kim YH, Kwon SM, Tang ZY, et al. Association of TP53 mutations with stem cell-like gene expression and survival of patients with hepatocellular carcinoma. Gastroenterology. 2011;140:1063-70. http://dx.doi.org/10.1053/j.gastro.2010.11.034

146. Ji J, Wang XW. Clinical implications of cancer stem cell biology in hepatocellular carcinoma. Semin Oncol. 2012;39:461-72. http://dx.doi.org/10.1053/j.seminoncol.2012.05.011

147. Yang XR, Xu Y, Yu B, Zhou J, Qiu SJ, Shi GM, et al. High expression levels of putative hepatic stem/ progenitor cell biomarkers related to tumour angiogenesis and poor prognosis of hepatocellular carcinoma. Gut. 2010;59:953-62. http://dx.doi.org/10.1136/gut.2008.176271

148. Sun YF, Xu Y, Yang XR, Guo W, Zhang X, Qiu SJ, et al. Circulating stem cell-like epithelial cell adhesion molecule-positive tumor cells indicate poor prognosis of hepatocellular carcinoma after curative resection. Hepatology. 2013;57:1458-68. http://dx.doi.org/10.1002/hep.26151

149. Nio K, Yamashita T, Kaneko S. The evolving concept of liver cancer stem cells. Mol Cancer. 2017;16:4. http://dx.doi.org/10.1186/s12943-016-0572-9

150. Smith LM, Nesterova A, Ryan MC, Duniho S, Jonas M, Anderson M, et al. CD133/prominin-1 is a potential therapeutic target for antibody-drug conjugates in hepatocellular and gastric cancers. $\mathrm{Br} \mathrm{J}$ Cancer. 2008;99:100-9. http://dx.doi.org/10.1038/sj.bjc.6604437

151. Gedaly R, Galuppo R, Daily MF, Shah M, Maynard E, Chen C, et al. Targeting the Wnt/beta-catenin signaling pathway in liver cancer stem cells and hepatocellular carcinoma cell lines with FH535. PLoS One. 2014;9:e99272. http://dx.doi.org/10.1371/journal.pone.0099272

152. Kim JY, Lee HY, Park KK, Choi YK, Nam JS, Hong IS. CWP232228 targets liver cancer stem cells through Wnt/beta-catenin signaling: A novel therapeutic approach for liver cancer treatment. Oncotarget. 2016;7:20395-409. http://dx.doi.org/10.18632/oncotarget.7954

153. Seto K, Sakabe T, Itaba N, Azumi J, Oka H, Morimoto M, et al. A Novel small-molecule WNT inhibitor, IC-2, has the potential to suppress liver cancer stem cells. Anticancer Res. 2017;37:3569-79. http://dx.doi.org/10.21873/anticanres.11727

154. He G, Cao X, He M, Sheng X, Wu Y, Ai X. Casticin inhibits self-renewal of liver cancer stem cells from the MHCC97 cell line. Oncol Lett. 2014;7:2023-8. http://dx.doi.org/10.3892/ol.2014.1972

155. Quan MF, Xiao LH, Liu ZH, Guo H, Ren KQ, Liu F, et al. 8-bromo-7-methoxychrysin inhibits properties of liver cancer stem cells via downregulation of beta-catenin. World J Gastroenterol. 2013;19:7680-95. http://dx.doi.org/10.3748/wjg.v19.i43.7680

156. Lee TK, Castilho A, Cheung VC, Tang KH, Ma S, Ng IO. Lupeol targets liver tumor-initiating cells through phosphatase and tensin homolog modulation. Hepatology. 2011;53:160-70. http://dx.doi. org/10.1002/hep. 24000

157. Kamiya A, Kinoshita T, Ito Y, Matsui T, Morikawa Y, Senba E, et al. Fetal liver development requires a paracrine action of oncostatin M through the gp130 signal transducer. EMBO J. 1999;18:2127-36. http://dx.doi.org/10.1093/emboj/18.8.2127

158. Yamashita T, Honda M, Nio K, Nakamoto Y, Yamashita T, Takamura H, et al. Oncostatin m renders epithelial cell adhesion molecule-positive liver cancer stem cells sensitive to 5-Fluorouracil by inducing hepatocytic differentiation. Cancer Res. 2010;70:4687-97. http://dx.doi.org/10.1158/0008-5472. CAN-09-4210 
159. Yin C, Lin Y, Zhang X, Chen YX, Zeng X, Yue HY, et al. Differentiation therapy of hepatocellular carcinoma in mice with recombinant adenovirus carrying hepatocyte nuclear factor-4alpha gene. Hepatology. 2008;48:1528-39. http://dx.doi.org/10.1002/hep.22510

160. Tomuleasa C, Soritau O, Fischer-Fodor E, Pop T, Susman S, Mosteanu O, et al. Arsenic trioxide plus cisplatin/interferon alpha-2b/doxorubicin/capecitabine combination chemotherapy for unresectable hepatocellular carcinoma. Hematol Oncol Stem Cell Ther. 2011;4:60-6. http://dx.doi. org/10.5144/1658-3876.2011.60

161. Zhang Y, Guan DX, Shi J, Gao H, Li JJ, Zhao JS, et al. All-trans retinoic acid potentiates the chemotherapeutic effect of cisplatin by inducing differentiation of tumor initiating cells in liver cancer. J Hepatol. 2013;59:1255-63. http://dx.doi.org/10.1016/j.jhep.2013.07.009

162. Zhang L, Sun H, Zhao F, Lu P, Ge C, Li H, et al. BMP4 administration induces differentiation of CD133+ hepatic cancer stem cells, blocking their contributions to hepatocellular carcinoma. Cancer Res. 2012;72:4276-85. http://dx.doi.org/10.1158/0008-5472.CAN-12-1013

163. Wolf B, Krieg K, Falk C, Breuhahn K, Keppeler H, Biedermann T, et al. Inducing differentiation of premalignant hepatic cells as a novel therapeutic strategy in hepatocarcinoma. Cancer Res. 2016;76:5550-61. http://dx.doi.org/10.1158/0008-5472.CAN-15-3453

164. Gao H, Li K, Tu H, Pan X, Jiang H, Shi B, et al. Development of T cells redirected to glypican-3 for the treatment of hepatocellular carcinoma. Clin Cancer Res. 2014;20:6418-28. http://dx.doi. org/10.1158/1078-0432.CCR-14-1170

165. Aleksieva N, Forbes SJ. Biliary-derived hepatocytes in chronic liver injury: Bringing new troops to the battlefield? J Hepatol. 2019;70:1051-3. http://dx.doi.org/10.1016/j.jhep.2019.03.015

166. Merrell AJ, Stanger BZ. Adult cell plasticity in vivo: De-differentiation and transdifferentiation are back in style. Nat Rev Mol Cell Biol. 2016;17:413-25. http://dx.doi.org/10.1038/nrm.2016.24

167. Tirnitz-Parker JEE, Forbes SJ, Olynyk JK, Ramm GA. Cellular plasticity in liver regeneration: Spotlight on cholangiocytes. Hepatology. 2019;69:2286-9. http://dx.doi.org/10.1002/hep.30340

168. Song K, Kwon H, Han C, Zhang J, Dash S, Lim K, et al. Active glycolytic metabolism in CD133(+) hepatocellular cancer stem cells: Regulation by MIR-122. Oncotarget. 2015;6:40822-35. http:// dx.doi.org/10.18632/oncotarget.5812

169. Zhang XL, Jia Q, Lv L, Deng T, Gao J. Tumorspheres derived from HCC cells are enriched with cancer stem cell-like cells and present high chemoresistance dependent on the Akt pathway. Anticancer Agents Med Chem. 2015;15:755-63. http://dx.doi.org/10.2174/1871520615666150202111721

170. Wang XQ, Ongkeko WM, Chen L, Yang ZF, Lu P, Chen KK, et al. Octamer 4 (Oct4) mediates chemotherapeutic drug resistance in liver cancer cells through a potential Oct4-AKT-ATP-binding cassette G2 pathway. Hepatology. 2010;52:528-39. http://dx.doi.org/10.1002/hep.23692 